\title{
POTENTIODYNAMIC BEHAVIOUR OF GRAPHITE AND PLATINUM ELECTRODES IN MOLTEN SODIUM NITRATE-POTASSIUM NITRATE EUTECTIC
}

\author{
M. G. Sustersic, W. E. Triaca and A. J. Arvía \\ Instituto de Investigaciones Físicoquimicas Téoricas y Aplicadas, División Electroquímica, \\ Facultad de Ciencias Exactas, Universidad Nacional de La Plata, La Plata, Argentina
}

(Received October 1972; in final form June 1973)

\begin{abstract}
The electrochemical behaviour of graphite and platinum electrodes has been studied in molten alkaline nitrates using cyclic voltammetry. The voltammograms obtained with graphite exhibit two current peaks not observed on platinum under similar conditions. An electrochemical reaction involving $\mathrm{O}_{2}^{-}$ ion and NO has been shown to proceed via an oxide on the graphite electrode surface which can be electrochemically reduced. It was assumed the formation of the $\mathrm{NO}_{3}$ intermediate is mainly responsible of the corrosion of the graphite in this melt. The thermal and electrochemical properties of graphite in the molten alkaline nitrate have been correlated.
\end{abstract}

\section{INTRODUCTION}

In a previous study of the sodium nitrate-potassium nitrate melt at temperatures from 230 to $470^{\circ} \mathrm{C}$, marked changes in the electrode surface and electrode reaction of graphite anodes were observed[1,2]. They became more marked at higher temperatures. suggesting the formation of an intermediate oxidised graphite surface. A similar explanation has been given of the anodic processes of graphite in molten potassium bisulphate[3].

Considering the technical importance of graphite as an electrode material it is interesting to study its chemical and electrochemical behaviour under both stationary and non-stationary conditions. The present research attempts to explain the surface reactions occurring on graphite in molten alkaline nitrates by using the linear potential sweep technique and to compare the behaviour of graphite with that of platinum electrodes in the same melt.

\section{EXPERIMENTAL}

The electrolysis cell consisted of a gas-tight Pyrex glass cylindrical container with a flanged cover supporting the different electrodes. Spectroscopic graphite rods (AGKSP) of either 3 or $6 \mathrm{~mm}$ dia were used as working electrodes. The apparent electrode areas were from 0.15 to $4 \mathrm{~cm}^{2}$, the area boundary being sometimes delimited by painting the rest of the electode surface with boron nitride. The counterelectrode was a platinum spiral placed into a separate fritted disc compartment. The reference electrode was a $\mathrm{Ag} / \mathrm{Ag}^{+}\left(\mathrm{AgNO}_{3}\right.$ $0.07 M$ ) electrode connected through the usual Luggin-Haber capillary arrangement. The pseudo-ohmic drop was always lower than $1 \mathrm{mV}$.
The electrolyte $\left(1: 1 \mathrm{NaNO}_{3}-\mathrm{KNO}_{3}\right)$ was prepared from A.R. chemicals vacuum dehydrated at $220^{\circ} \mathrm{C}$ and kept under pure nitrogen. A.R. quality gases were employed in the experiments $\left(\mathrm{N}_{2}, \mathrm{O}_{2}, \mathrm{CO}_{2}, \mathrm{NO}_{2}\right.$ and $\mathrm{NO}$ ). Both $\mathrm{NO}_{2}$ or $\mathrm{NO}$ were collected at the cell outlet.

Experiments were carried out in the temperature range $240-350 \pm 1^{\circ} \mathrm{C}$. The linear potential sweep technique is described elsewhere[4].

\section{RESULTS AND INTERPRETATION}

\section{Current-potential curves}

Semilogarithmic plots of stationary potentiostatic anodic $E-I$ curves with graphite anodes fit, at potentials $<0.6 \mathrm{~V}$, reasonable straight lines with slopes slightly higher than $2.3(R T / F)$. At $0.6 \mathrm{~V}$ a limiting current is observed, related to the oxidation of the nitrite ion which is present in the melt, and proportional to its concentration. At potentials $>0.6 \mathrm{~V}$, another straight line is exhibited, with a slope $\approx 2 \cdot 3(2 R T / F)$. This is the potential region where the $\mathrm{NO}_{3}^{-}$ion discharge takes place.

\section{Voltammograms with graphite electrodes}

Prediminury results. When a graphite electrode previously baked in air at $360^{\circ} \mathrm{C}$ is dipped into a dehydrated nitrate melt, a rest potential of $0 \cdot 15-0.20 \mathrm{~V}$ is attained. A voltammogram obtained by sweeping the potential from -0.3 to $0.6 \mathrm{~V}$, at $50 \mathrm{mV} / \mathrm{s}$, shows during the first sweep an anodic current peak at $0.575 \mathrm{~V}$ and during the returning half-cycle a cathodic current peak at $0.475 \mathrm{~V}$. During repetitive potential sweeps an appreciable increase of the voltammogram area is noticed and a new anodic wave located at ca $0.32-$ $0.35 \mathrm{~V}$ occurs. 


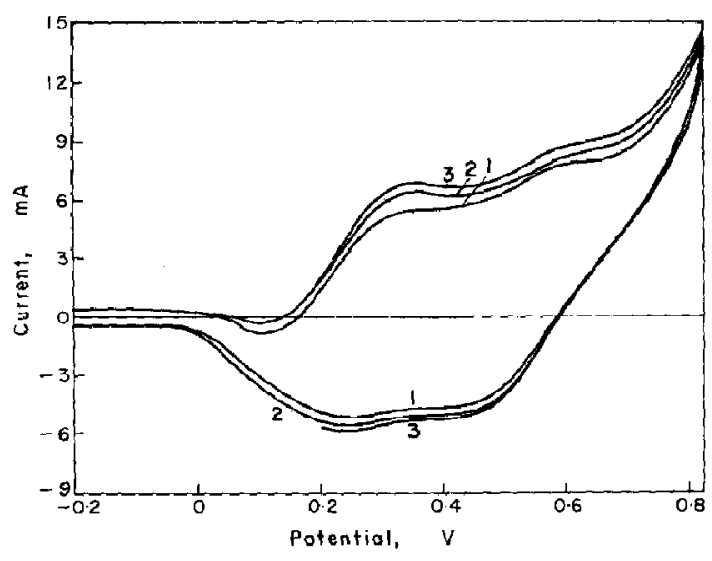

Fig. 1. Voltammogram obtained with the graphite/molten nitrate system at $10 \mathrm{mV} / \mathrm{s}$ and $244^{\circ} \mathrm{C}$. The numbers correspond to the successive potential sweeps.

After 2 days in the melt the graphite electrode attained a rest potential of $0.07 \mathrm{~V}$. Under this condition, the voltammograms obtained either at 5,10 or $50 \mathrm{mV} / \mathrm{s}$, from -0.3 to $0.8 \mathrm{~V}$, exhibit an anodic current peak between 0.30 and $0.35 \mathrm{~V}$ and a cathodic current peak at $0.225 \mathrm{~V}$. These current peaks are better defined at lower potential sweep rates, as shown in Fig. 1. There is an anodic current plateau between -0.3 and $0.2 \mathrm{~V}$ which, as further referred, is related to the electrochemical oxidation of $\mathrm{OH}^{-}$ions. The voltammograms run with graphite electrodes previously aged in the melt present an area much larger than the area of the votammograms obtained with fresh graphite electrodes. When graphite electrodes were not previously baked in air, the effect was not found. The increase of area starting only when the electrolysis proceeds at anodic potentials larger than that corresponding to the $\mathrm{NO}_{2}^{-}$ion discharge.

\section{Anodic oxidation of nitrite}

To identify the anodic current peak related to the $\mathrm{NO}_{2}^{-}$ion oxidation, $\mathrm{KNO}_{2}$ (up to $15 \times 10^{-2} \mathrm{M}$ ) was added to the melt. The latter always contained some nitrite, probably in part formed by decomposition of nitrate during the dehydration treatment and in part present as an initial impurity. Single sweep voltammograms show an increase of the anodic current peak at ca $0.575 \mathrm{~V}$ and a simultaneous shift of the peak potential towards more positive values with the increase of $\mathrm{NO}_{2}^{-}$ion concentration. This potential shift can be due either to a non-compensated ohmic drop, which is rather unlikely because of the currents involved and the large electrical conductance of the system, or to the fact that the electrochemical oxidation of $\mathrm{NO}_{2}^{-}$ion becomes more irreversible as its concentration is increased, as was discussed elsewhere [5]. The peak current related to the anodic oxidation of $\mathrm{NO}_{2}^{-}$ion occurs in a similar way on platinum electrodes.
4. Comparison of the system graphite/molten nitrate to the system platinum/molten nitrate

For reference purposes voltammograms were recorded with the system platinum/nitrate melt from 0 to $0.8 \mathrm{~V}$ at $244^{\circ} \mathrm{C}$, where only the $\mathrm{NO}_{2}^{-} / \mathrm{NO}_{2}$ couple is observed (Fig. 2). Further, similar to what was reported by Zambonin[6], the following observations were made on voltammograms run from -2.1 to $-0.3 \mathrm{~V}$, (Fig. 3): (i) One cathodic current peak which is related to the electrochernical reduction of $\mathrm{NO}_{3}^{-}-\mathrm{NO}_{2}^{-}$ and the simultaneous formation and precipitation of an alkali metal oxide on the electrode. The maximum current shifts towards more cathodic potentials when the potential sweep rate increases from 50 to $300 \mathrm{mV} / \mathrm{s}$; (ii) An anodic current peak at $-1.0 \mathrm{~V}$, assigned to the electrochemical dissolution of the oxide, which also shifts with the potential sweep rate; (iii) An anodic current peak which corresponds to the discharge of the $\mathrm{O}_{2}^{-}$ion. As seen in Fig. 3, the voltammogram shape obtained for the first potential sweep differs from the following ones, but a stationary shape is reached after the third cycle. Furthermore, no appreciable change of the voltammogram area is noticed in subsequent sweeps.

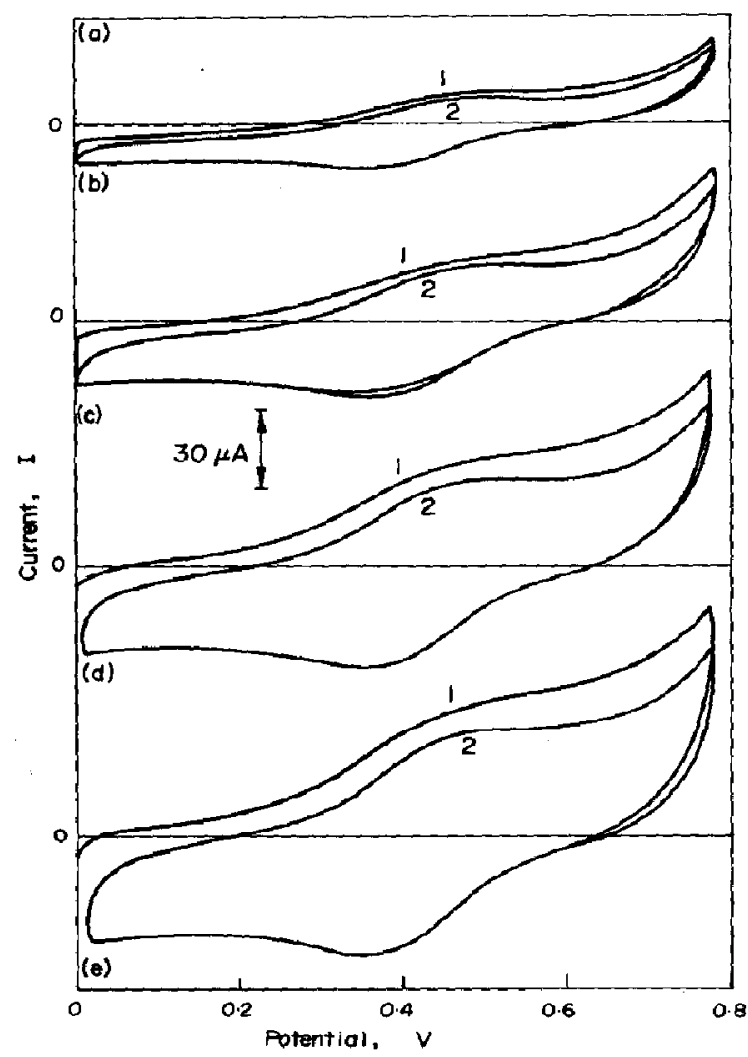

Fig. 2. Voltammograms obtained with the platinum/molten nitrate system at (a) 50 ; (b) 100 ; (c) 200 and (d) $300 \mathrm{mV} / \mathrm{s}$ and $244^{\circ} \mathrm{C}$ 


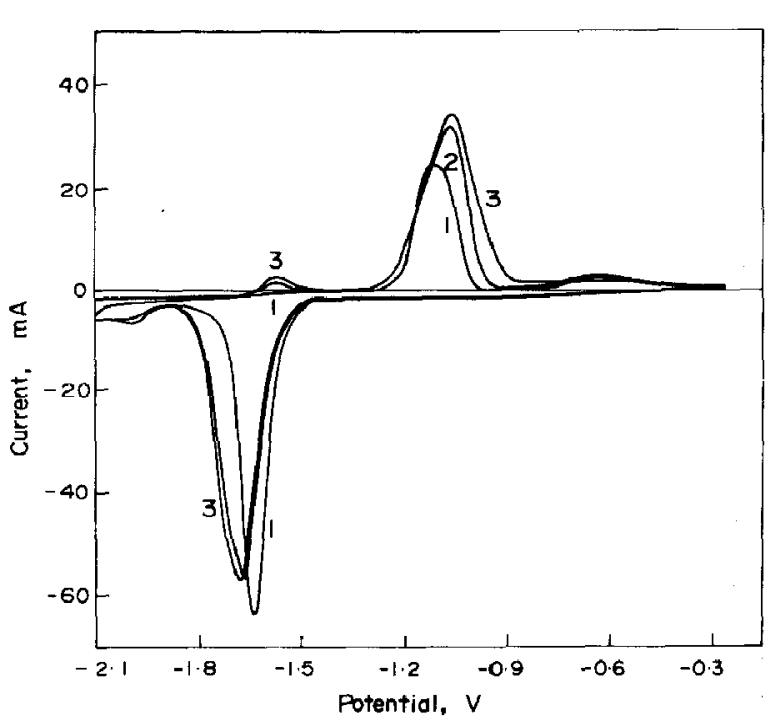

Fig. 3. Voltammograms obtained with the platinum/molten nitrate system starting from cathodic potentials at $300 \mathrm{mV} / \mathrm{s}$ and $245^{\circ} \mathrm{C}$.

The anodic current peak related to $\mathrm{O}_{2}^{-}$ion reduction is evidenced only when the melt is electrolysed at cathodic potentials $(-1 \cdot 5 ;-1 \cdot 2 \mathrm{~V})$. This current peak appears equally well during the first potential sweep either with platinum or with graphite, and its location $(\mathrm{ca}-0.6 \mathrm{~V})$ seems to be independent of the potential sweep rate. However, on graphite electrodes in the same potential region a cathodic current peak is observed, probably related to the reduction of $\mathrm{O}_{2}$ to $\mathrm{O}_{2}^{-}$.

The anodic current peak for $\mathrm{OH}$ ion oxidation is recorded after a previous cathodisation of the melt (Fig. 4). The pre-cathodisation is made at $-1.0 \mathrm{~V}$, its duration affecting the height of the $\mathrm{OH}^{-}$ion oxidation peak, as shown in Fig. 4 for the graphite-molten nitrate system at $350^{\circ} \mathrm{C}$. According to Zambonin[6], the occurrence of this peak is due to the $\mathrm{O}_{2}^{2-}$ ion and to the presence of traces of water which react yielding $\mathrm{O}_{2}^{-}$ and $\mathrm{OH}^{-}$ions. Both reaction products are picked up in the voltammogram. The detection of the $\mathrm{OH}^{-}$ion current peak was made by adding known quantities of $\mathrm{NaOH}$ to the melt. The peak height increases as the $\mathrm{NaOH}$ concentration does; the peak on graphite is less defined than that on platinum. Furthermore, the peak potential shifts both with increasing the $\mathrm{OH}^{-}$ion concentration and with increasing the potential sweep rate towards more anodic potentials. Apparently linear potential-log (potential sweep rate) and linear peak height-square root of potential sweep rate relationships are obeyed for the anodic $\mathrm{OH}^{-}$ion current peak, as described further on. Consequently, current peaks formerly identified on platinum are also found on graphite together with two new peaks, one comprising an anodic current at a potential $(0 \cdot 3-0 \cdot 4 \mathrm{~V})$ preceding the anodic $\mathrm{NO}_{2}^{-}$ion discharge and another involving a cathodic current within the potential region $0 \cdot 2-0 \cdot 3 \mathrm{~V}$.

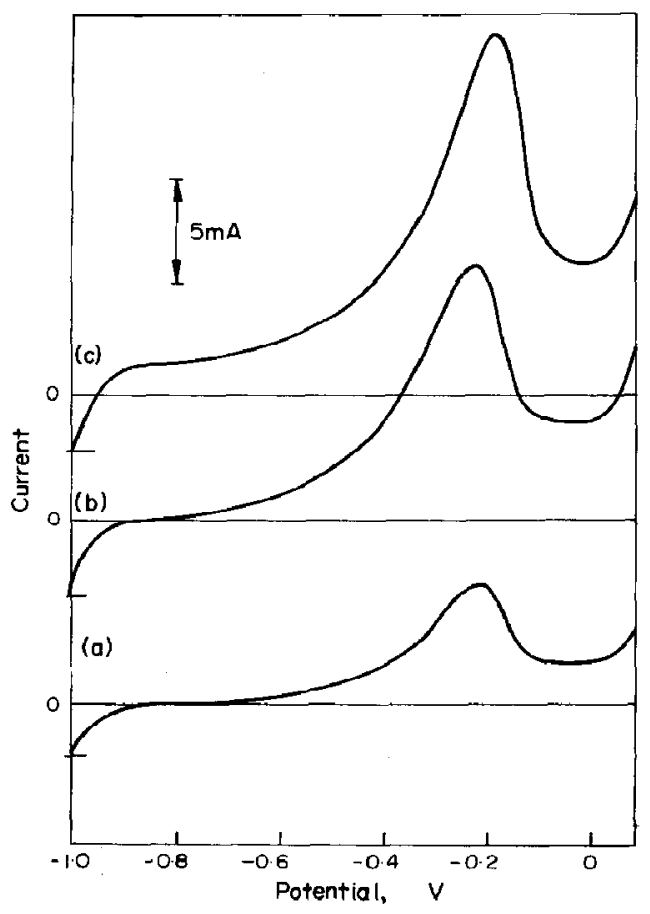

Fig. 4. Influence of the pre-electrolysis time at $-1 \mathrm{~V}$, on the $\mathrm{OH}^{-}$ion oxidation current peak for graphite/nitrate melt. (a) $0.5 \mathrm{~m}$; (b) $1 \mathrm{~m}$; (c) $3 \mathrm{~m} ; 50 \mathrm{mV} / \mathrm{s} ; 349^{\circ} \mathrm{C}$.

\section{Identification of new current peaks on graphite}

(i) Effect of anodisation. The two now current peaks are not observed during the first potential sweep when new electodes and electrolyte are used if the potential amplitude is restricted to $00.7 \mathrm{~V}$ and the region where the electrochemical oxidation of $\mathrm{NO}_{3}^{-}$ion takes place is avoided. The peaks, however, appear definitely during the subsequent potential sweeps, and increase markedly from one sweep to the following one (Fig. 5). When potential sweeps from 0 to $0.4 \mathrm{~V}$ are made, this effect is not observed. Both current peaks are reduced

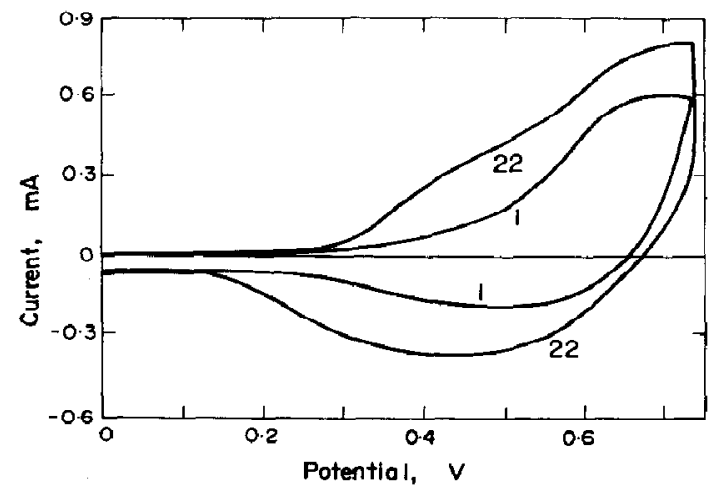

Fig. 5. Effect of the repetitive potential sweeping on the voltammograms of the graphite/molten nitrate system; $50 \mathrm{mV} / \mathrm{s} ; 345^{\circ} \mathrm{C}$. 


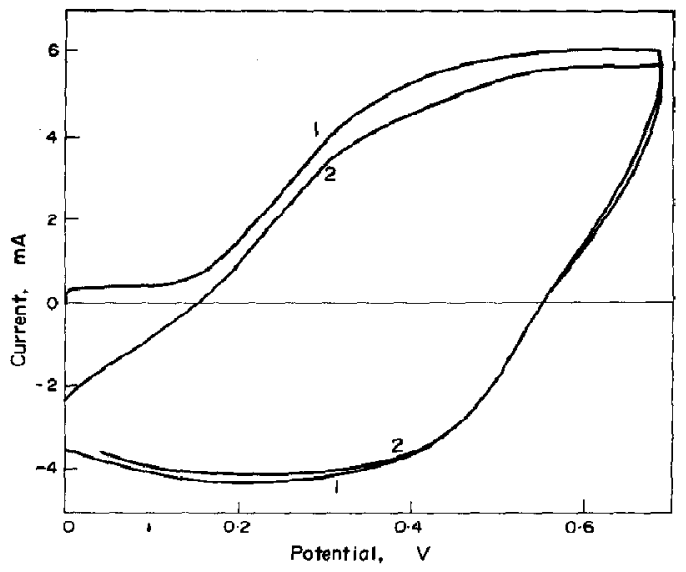

Fig. 6. Voltammograms recorded for the graphite/nitrate melt after a $1 \mathrm{~min}$ preanodisation at $1 \mathrm{~V} ; 50 \mathrm{mV} / \mathrm{s} ; 245^{\circ} \mathrm{C}$.

when $N_{2}$ is bubbled but they increase markedly after anodisation at $1.0 \mathrm{~V}$ for $1 \mathrm{~min}$ (Fig. 6). This effect indicates these peaks relate to substances yielded by the anodic reaction of either $\mathrm{NO}_{2}^{-}$or $\mathrm{NO}_{3}^{-}$ions or both.

(ii) Effect of nitrogen dioxide. When $\mathrm{NO}_{2}$ is bubbled through the electrolyte to the point of saturation, the graphite rest potential is $0610 \mathrm{~V}$ at $243^{\circ} \mathrm{C}$. (Saturation of the melt with $\mathrm{NO}_{2}$ requires $\$ 24 \mathrm{~h}$.) If the $\mathrm{NO}_{2}$ is removed, the rest potential decreases to $-0.19 \mathrm{~V}$. Sweeping the potential from 0 to $0.4 \mathrm{~V}$, to avoid the interference of $\mathrm{NO}_{2}$ produced in the discharge of the $\mathrm{NO}_{2}^{-}$ion, the two new current peaks increase markedly in the presence of $\mathrm{NO}_{2}$ (Figs. 7a and 7b). Furthermore, when $\mathrm{NO}_{2}$ is removed by bubbling $\mathrm{N}_{2}$, an increase of the voltammogram area is observed (Fig. 8).

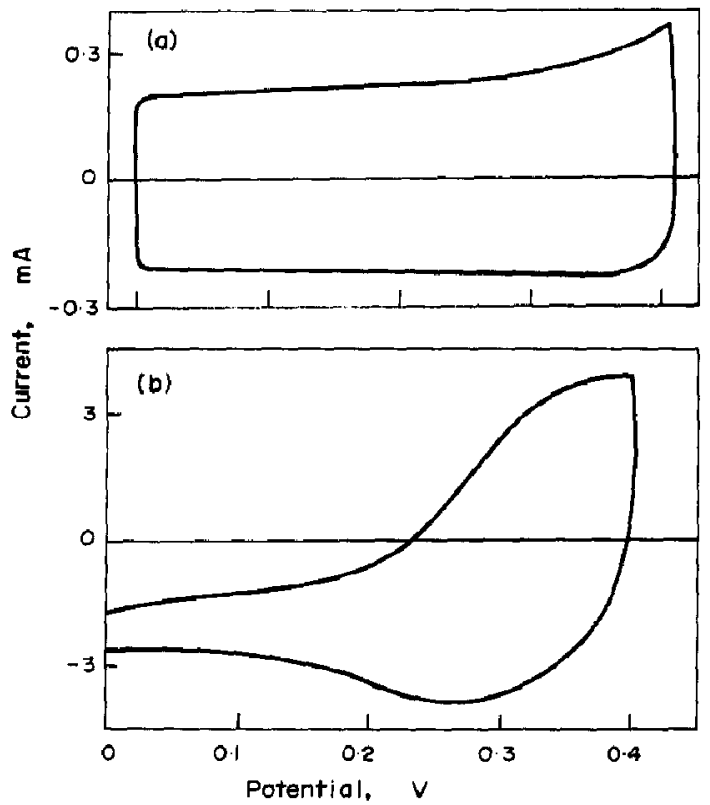

Fig. 7. Influence of the $\mathrm{NO}_{2}$ saturation. Graphite/nitrate melt. (a) blank; (b) with $\mathrm{NO}_{2} ; 50 \mathrm{mV} / \mathrm{s} ; 245^{\circ} \mathrm{C}$.

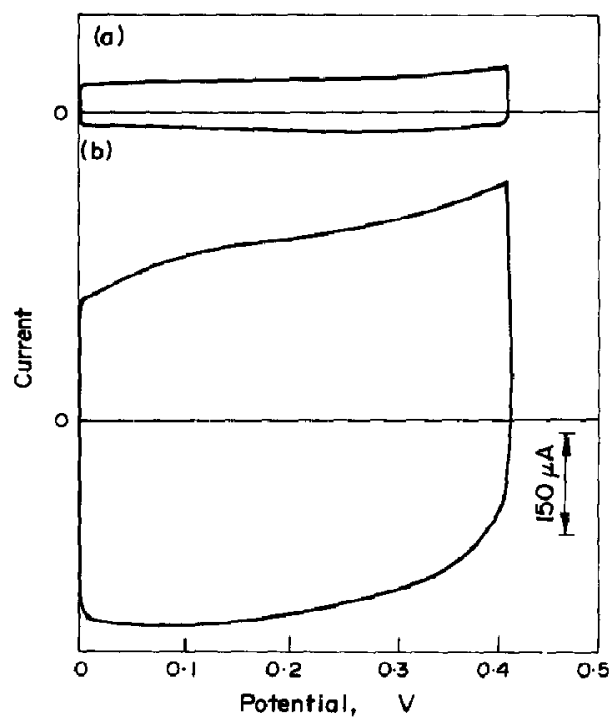

Fig, 8. Change of the electrode area of the graphite due to $\mathrm{NO}_{2}$. (a) blank; (b) after $\mathrm{NO}_{2}$ bubbling and climination by nitrogen; $50 \mathrm{mV} / \mathrm{s} ; 245^{\circ} \mathrm{C}$.

On platinum electrodes the saturation of the melt with $\mathrm{NO}_{2}$ produces an increase of the current peaks related to the $\mathrm{NO}_{2}^{-} / \mathrm{NO}_{2}$ couple.

(iii) Effect of cathodisation on graphite and platinum. When a graphite electrode is cathodised during $1 \mathrm{~min}$ at $-1.0 \mathrm{~V}$ and afterwards a voltammogram is run from 0 to $0.4 \mathrm{~V}$, both new current peaks increase as compared to the blank (Fig. 9). The increase, however, is

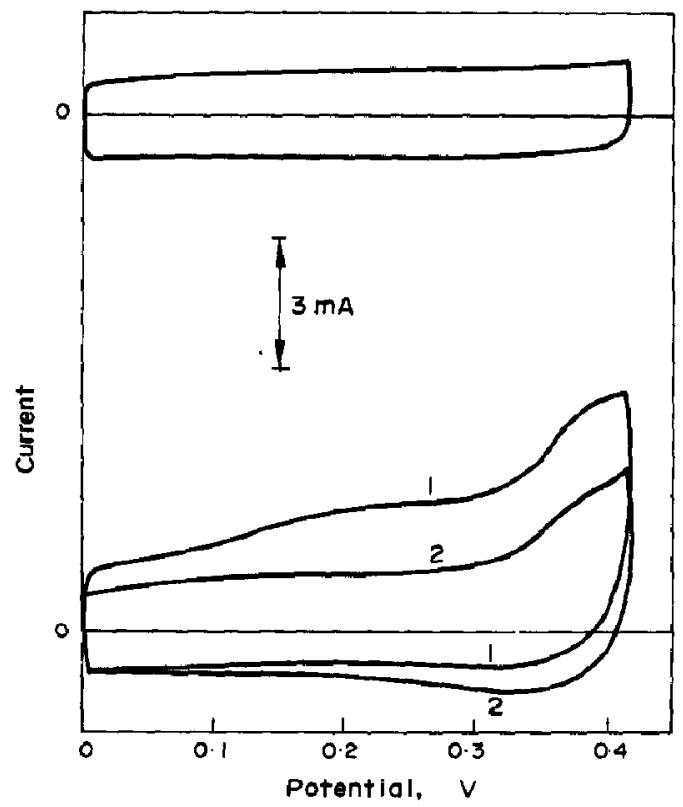

Fig. 9. Influence of the pre-electrolysis time at $-1 \mathrm{~V}$. Graphite/nitrate melt; (a) blank; (b) $1 \mathrm{~m} ; 50 \mathrm{mV} / \mathrm{s} ; 245^{\circ} \mathrm{C}$. 


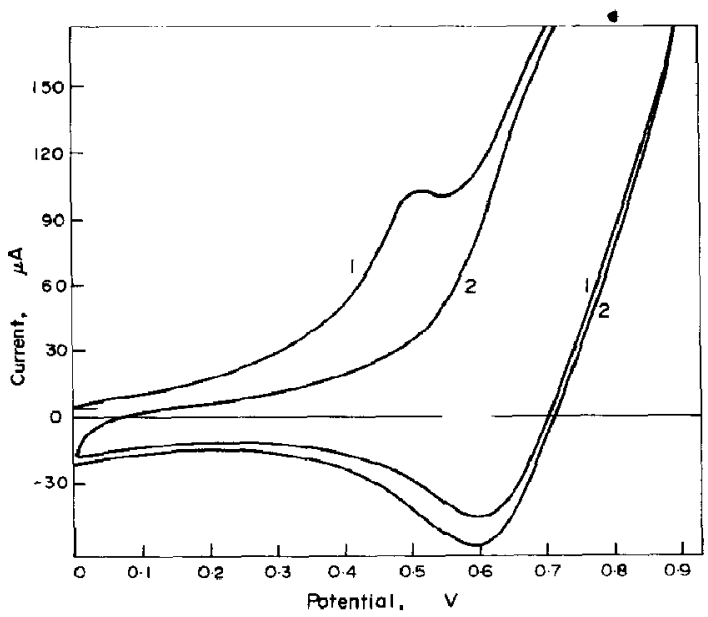

Fig. 10. Influence of the pre-elcctrolysis time at $-1 \mathrm{~V}$; platinum/nitrate melt; $100 \mathrm{mV} / \mathrm{s}: 244^{\circ} \mathrm{C}$.

not as large as that observed alter a previous anodisation.

If the same experiments are repeated with a platinum electrode, only during the first potential sweep is the anodic current peak observed (Fig. 10). However, by running the voltammogram from -1.0 to $0.5 \mathrm{~V}$, the same current peak appears at any potential sweep.

(iv) Effect of nitric oxide. The NO does not react with graphite which under NO saturation exhihits a rest potential equal to $0.342 \mathrm{~V}$ at $244^{\circ} \mathrm{C}$. When formation of $\mathrm{NO}_{2}$ occurs the potential becomes more positive up to $0.610 \mathrm{~V}$. A voltammogram obtained under NO saturation shows the height increase of the two peaks already mentioned and the peak potentials become more anodic $(c a 0.1 \mathrm{~V})$. According to this, if the equilibrium[7],

$$
\mathrm{NO}+\mathrm{NO}_{3}^{-}=\mathrm{NO}_{2}+\mathrm{NO}_{2}^{-}
$$

is taken in to account, the question is whether $\mathrm{NO}_{2}$ or NO react at the electrode. Saturation with nitric oxide has no appreciable effect on the voltammogram on the platinum/molten nitrate system. There is only an increase of the $\mathrm{NO}_{2}^{-}$ion current peak, due to equilibrium (1). But after the system has been cathodised at $-1.2 \mathrm{~V}$, the anodic current peak appears as already mentioned in (iii) and it is observed only during the first potential sweep.

(v) Effect of sodium peroxide. When $\mathrm{Na}_{2} \mathrm{O}_{2}$ is added to the melt it becomes turbid and gas $\left(\mathrm{O}_{2}\right)$ is evolved and the graphite rest potential becomes more negative and stabilised at $-0.7 \mathrm{~V}$ at $242^{\circ} \mathrm{C}$. Voltammograms swept between 0 and $0.7 \mathrm{~V}$, reproduce the blanks but those run between -1.0 and $0.7 \mathrm{~V}$ exhibit two well-defined oxidation current peaks, one at $-0.6 \mathrm{~V}$, corresponding to the oxidation of $\mathrm{O}_{2}^{-}$ion to $\mathrm{O}_{2}$. and another at $0 \mathrm{~V}$ corresponding to the oxidation of $\mathrm{OH}^{-}$ion. There is also one cathodic current peak at $-0.7 \mathrm{~V}$ which involves a reaction complementary to that of the former anodic current peak. Both anodic current peaks are clearly established during the first potential sweep and decreisc after successive cycling. The $\mathrm{OH}^{-}$ion oxidation peak is the one which decreases more markedly.

(vi) Effect of sodium peroxide and nitric oxide. The effects described in (v) indicate that the $\mathrm{O}_{2}^{-}$ion and $\mathrm{NO}$ (or $\mathrm{NO}_{2}$ ) may have a simultaneous effect on the electrochemical process (Fig. 11). The $\mathrm{O}_{2}^{-}$ion may, in principle, be generated through $\mathrm{O}^{2-}$ ion formation during the chemical oxidation of graphite by $\mathrm{NO}_{2}$, according to:

$$
2 \mathrm{C}+2 \mathrm{NO}_{3}^{-}+\mathrm{NO}_{2}=3 \mathrm{NO}+2 \mathrm{CO}_{2}+\mathrm{O}^{2-}
$$

or

$$
4 \mathrm{C}+2 \mathrm{NO}_{3}^{-}+\mathrm{NO}_{2}=3 \mathrm{NO}+4 \mathrm{CO}+\mathrm{O}^{2-} \text {. }
$$

These reactions are energetically favoured as deduced from the free energy change at $500^{\circ} \mathrm{K}$, of the following reactions:

$$
\begin{aligned}
2 \mathrm{C}(\mathrm{gr})+2 \mathrm{NaNO}_{3}(1)+\mathrm{NO}_{2}(\mathrm{~g}) \\
=3 \mathrm{NO}(\mathrm{g})+\mathrm{Na}_{2} \mathrm{O}(\mathrm{s})+2 \mathrm{CO}_{2}(\mathrm{~g}), \\
\Delta G^{0}=-89.657 \mathrm{kcal} / \mathrm{mole}
\end{aligned}
$$

and

$$
\begin{aligned}
4 \mathrm{C}(\mathrm{gr})+2 \mathrm{NaNO}_{3}(\mathrm{l})+\mathrm{NO}_{2}(\mathrm{~g}) & \\
& =3 \mathrm{NO}(\mathrm{g})+\mathrm{Na}_{2} \mathrm{O}(\mathrm{s})+4 \mathrm{CO}(\mathrm{g}), \\
\Delta G^{\prime \prime} & =-44 \cdot 628 \mathrm{kcal} / \mathrm{mole} .
\end{aligned}
$$

Therefore, should $\mathrm{O}_{2}^{2-}$ ion be supplied to the melt by adding $\mathrm{Na}_{2} \mathrm{O}_{2}$, the corresponding oxidation current peak would be observed on platinum during any cycle by sweeping within the anodic potential region.

The addition of $\mathrm{Na}_{2} \mathrm{O}_{2}$ to the platinum/nitrate system produces a shift of the rest potential towards more negative values. A similar effect should occur with the potential of the $\mathrm{NO}_{2}^{-} / \mathrm{NO}_{2}$ couple. If the melt is saturated with $\mathrm{NO}$ the rest potential incrcases up to $-0.04 \mathrm{~V}$ at $244^{\circ} \mathrm{C}$ and that of the $\mathrm{NO}_{2}^{-} \mathrm{NO}_{2}$ couple returns to its former value.

The anodic current peak on platinum is exhibited by any voltammogram at any cycling. The peak leeight decreases by $\mathrm{N}_{2}$ bubbling. Parallel results can be obtained with the graphite/nitrate melt. as shown in Fig. 12. Apparently there is no interference from the chemical reaction between graphite and NO.

Returning now to the graphite/nitrate melt, one must conclude that the existence of the anodic current peak is probably originated by $\mathrm{O}_{2}^{-}$ions which are chemically as well as electrochemically produced. On platinum, this peak occurs during the first sweep after it previous cathodisation, since on this metal there is no possibility of regenerating the $\mathrm{O}_{2}^{-}$ions if the potential sweep covers only the anodic potential region. This is confirmed by the fact that additions of $\mathrm{O}_{2}^{-}$ions and NO induce the occurrence of the anodic current peak at any cycle.

(vii) Increase of voltammogram area. The increase of voitammogram area with potential cycling of the graphite implies an increase of the electrode area produced by the surface attack during the electrochemical 


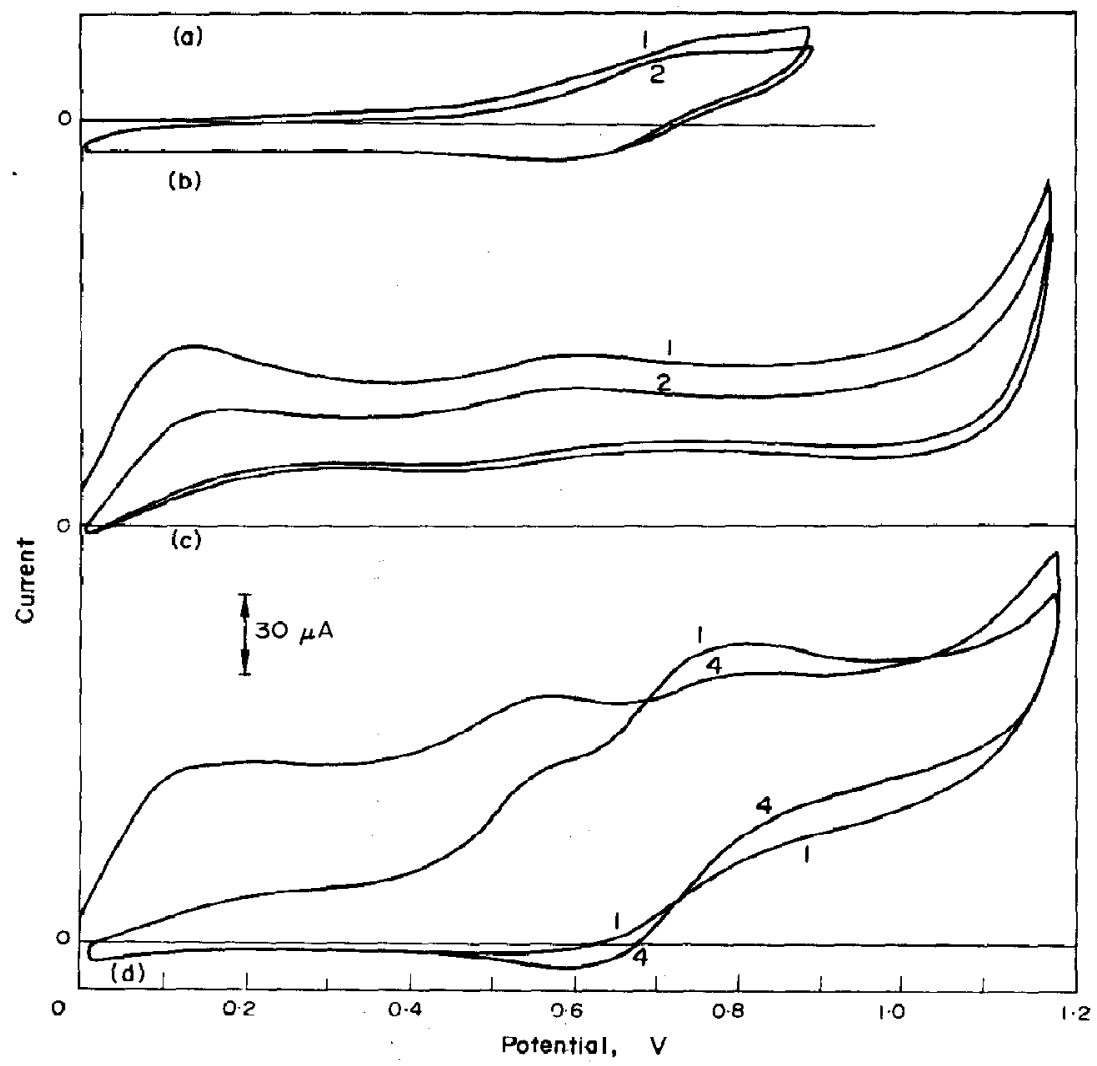

Fig. 11. Effect of $\mathrm{Na}_{2} \mathrm{O}+\mathrm{NO}$ addition on the voltammograms run with the platinum nitrate melt at $245^{\circ} \mathrm{C} ; 50 \mathrm{mV} / \mathrm{s}$. (a) $\mathrm{NO}_{2} / \mathrm{NO}_{2}^{-}$couple; (b) after the addition of $\mathrm{Na}_{2} \mathrm{O}_{2}$ (containing traces of $\mathrm{OH}^{-}$ion); (c) after the addition of $\mathrm{Na}_{2} \mathrm{O}_{2}$ and $\mathrm{NO}$ bubbling. The voltammogram is unchanged after the four th potential sweep.

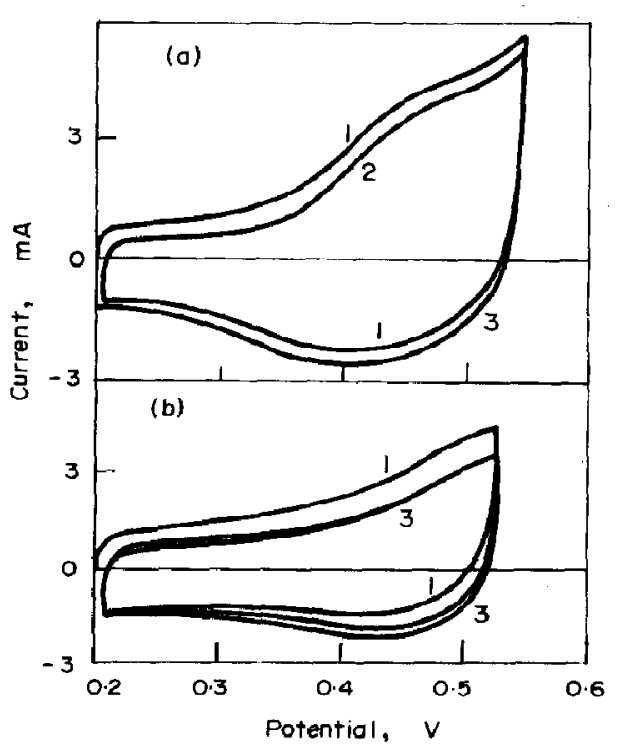

Fig. 12. Effect of $\mathrm{Na}_{2} \mathrm{O}_{2}+\mathrm{NO}$ addition on the voltammograms run with the graphite/nitrate melt; $50 \mathrm{mV} / \mathrm{s} ; 245^{\circ} \mathrm{C}$.

(a) blank; (b) after the addition of $\mathrm{Na}_{2} \mathrm{O}_{2}+\mathrm{NO}$. reaction when the anodic potential sweep exceeds the potential of the $\mathrm{NO}_{2}^{-} / \mathrm{NO}_{2}$ couple or when $\mathrm{NO}_{2}$ is bubbled through the melt. One must conclude, therefore, that $\mathrm{NO}_{2}$ is the entity mainly responsible for the corrosion of graphite.

(viii) Effect of sodium peroxide and nitrogen dioxide. To determine if either $\mathrm{NO}$ or $\mathrm{NO}_{2}$ produces the new anodic oxidation current peak, experiments described under section (vi) were repeated but in the presence of $\mathrm{NO}_{2}$ instead of $\mathrm{NO}$. In this case the $\mathrm{NO}_{2}^{-}$ion concentration was minimized by $\mathrm{NO}_{2}$ bubbling and, subsequently $\mathrm{NO}$ and $\mathrm{NO}_{2}$ were eliminated by bubbling $\mathrm{N}_{2}$ through the melt. Then $\mathrm{Na}_{2} \mathrm{O}_{2}$ was added and the melt saturated with $\mathrm{NO}_{2}$. Under these conditions the anodic current peak of the $\mathrm{O}_{2}^{-}$ion was no longer observed and the anodic current peak related to the $\mathrm{OH}^{-}$ion decreased as $\mathrm{NO}_{2}$ was bubbled. A similar effect was provoked by the presence of $\mathrm{NO}$, probably because $\mathrm{NO}_{2}$ was produced as an intermediate. It is reasonable, therefore, to conclude that the new anodic current peak is due to an electrochemical interaction of $\mathrm{NO}$ and $\mathrm{O}_{2}^{-}$ion.

(ix) Other additions to the system. It has also been proved that additions of $\mathrm{CO}_{2}, \mathrm{CO}, \mathrm{O}_{2}$ or $\mathrm{Na}_{2} \mathrm{CO}_{3}$ 


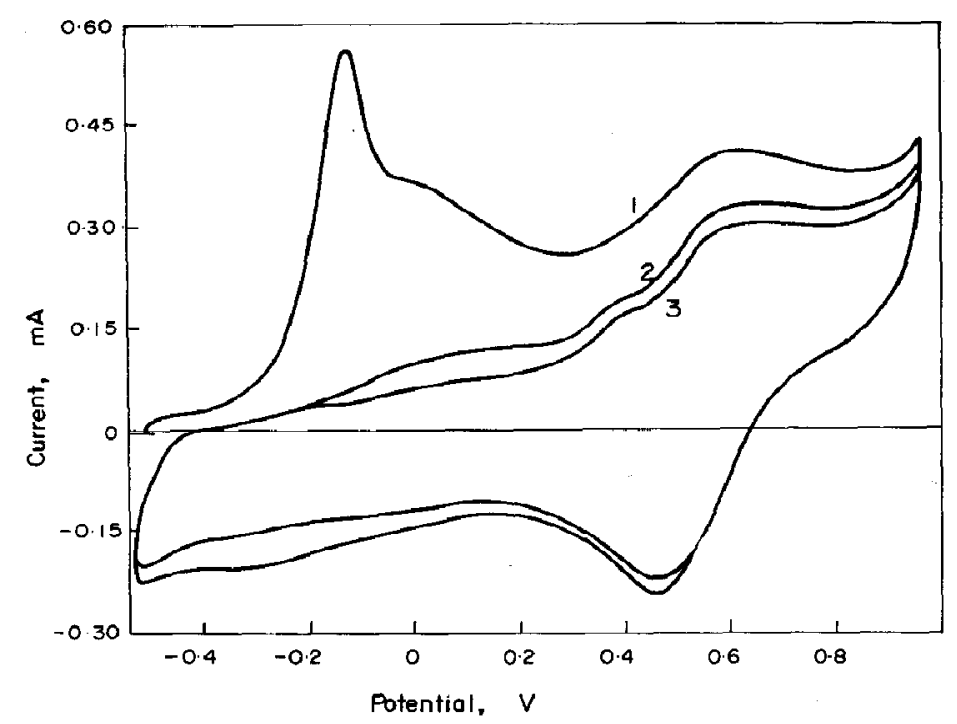

Fig. 13. Voltammograms run with the platinum/nitrate melt; $300 \mathrm{mV} / \mathrm{s} ; 292^{\circ} \mathrm{C}$.

cause no difference in the voltammogram display for the graphite/nitrate melt.

\section{Temperature effects}

(i) The platinum/molten nitrate system. Voltammograms obtained with this system from -0.5 to $0.7 \mathrm{~V}$ exhibit only the current peaks of the $\mathrm{NO}_{2}^{-} / \mathrm{NO}_{2}$ couple because of the nitrite present as a trace. At any constant potential, larger currents are observed as the temperature is raised and, as seen in Fig. 13, a new current peak at $0 \cdot 35-0.40 \mathrm{~V}$ is observed. The potential difference between this current peak and that of $\mathrm{NO}_{2}^{-}$ion oxidation is the same as that noted between the oxi- dation current peak just described and the $\mathrm{NO}_{2}^{-}$ion current peak. Hence, the temperature increase is equivalent to the addition of basic ions to the melt.

(ii) The graphite/molten nitrate system. With increasing temperature marked changes occur (Fig. 14). First a net gas evolution is observed without any external current flow. The rest potential, which becomes more negative when the temperature is increased, does not return to its original value if the temperature decreased. The anodic current peak corresponding to $\mathrm{OH}^{-}$ion oxidation is split, one peak located at $-0.2 \mathrm{~V}$ and the other at $0 \mathrm{~V}$ (Fig. 14). The former increases more markedly as temperature is increased. This effect,

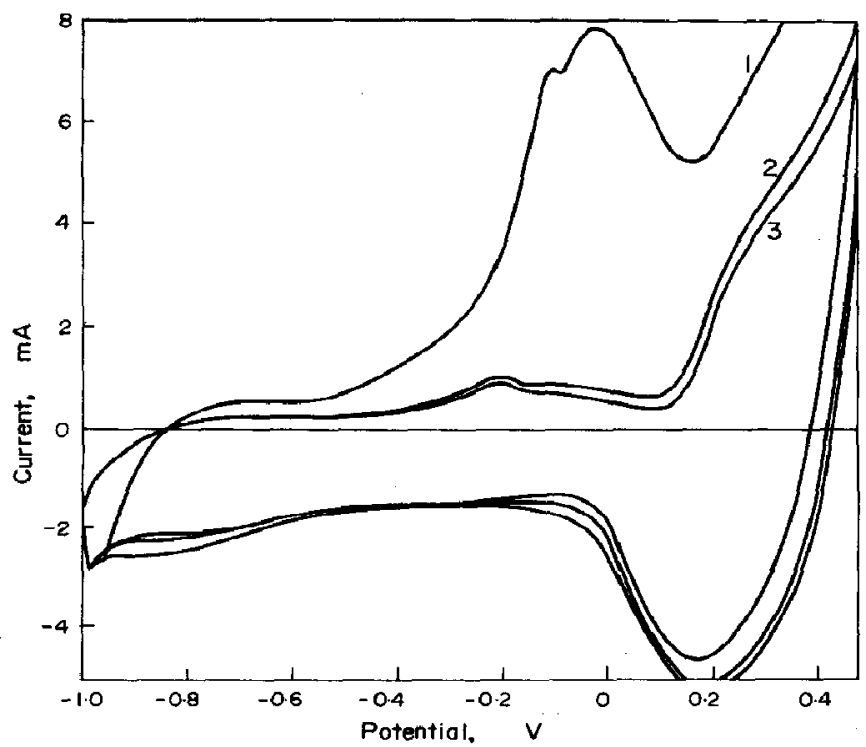

Fig. 14. Voltammograms run with the graphite/nitrate melt at $50 \mathrm{mV} / \mathrm{s} ; 292^{\circ} \mathrm{C}$. 
which has also been observed on platinum (Fig. 13) indicates that its occurrence is independent of the electrode material. With graphite electrodes, no change in the anodic peaks is observed but the cathodic current during the returning potential sweep is greatly lowered. Prohahly the current peaks exist but they are masked by the proper electrochemical reactions of nitrate ions, whose overvoltages decrease appreciably as temperautre is increased. If the graphite electrode is left immersed in the melt at $350^{\circ} \mathrm{C}$ for a long time, a net increase of the $\mathrm{OH}^{-}$ion oxidation peak is observed (Fig. 15).

In general, for both systems as the equilibrium superoxide $\rightleftharpoons$ peroxide $\rightleftharpoons$ oxide, shifts towards the right as temperature increases[6], the current peak related to the $\mathrm{O}_{2}^{-}+\mathrm{NO}$ slectrode reaction is no longer clearly observed at $345^{\circ} \mathrm{C}$.

7. Dependences of the various current peaks on the potential sweep rate

(i) The graphite/molten nitrate system. The heights of the new oxidation and reduction current peaks increase linearly with $v^{1 / 2}$ (Fig. 16) and $v$ respectively (Fig. 17). The oxidation current peak was corrected for the contribution of the $\mathrm{OH}^{-}$ion oxidation current. The plot of Fig. 17 involves the total peak current without any further correction.

The uncorrected peak height related to the $\mathrm{NO}_{2}^{-}$ion oxidation also depends linearly on $v^{1 / 2}$ (Fig. 18). Simi-

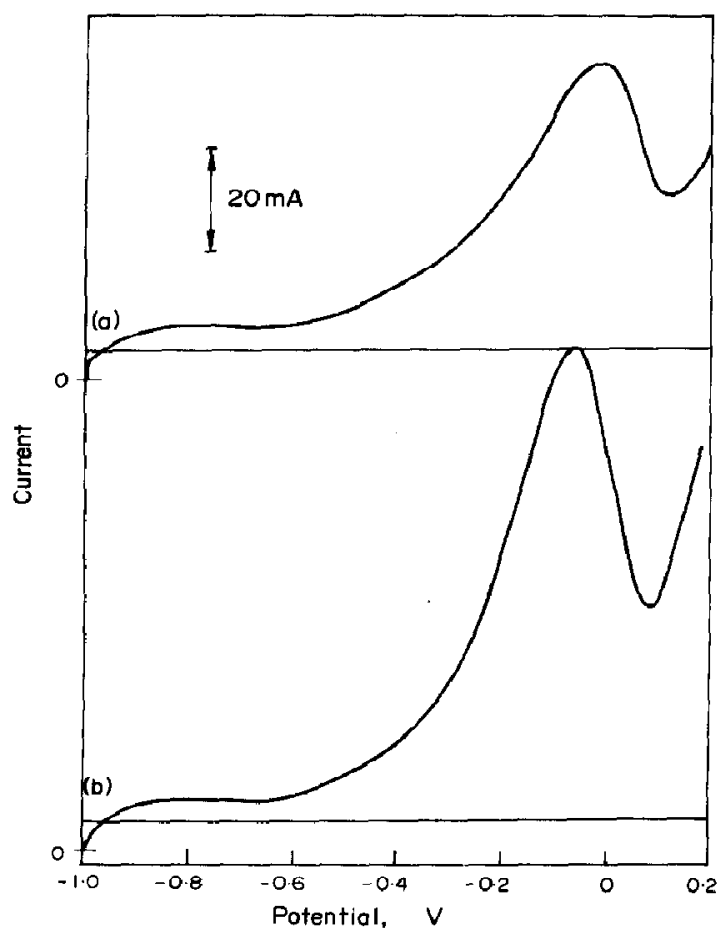

Fig. 15. Effect of immer sion time of gruphite electrodes on the voltammograms: $50 \mathrm{mV} / \mathrm{s}$ : $351^{C}$ C. (a) blank; (b) after overnight immersion.

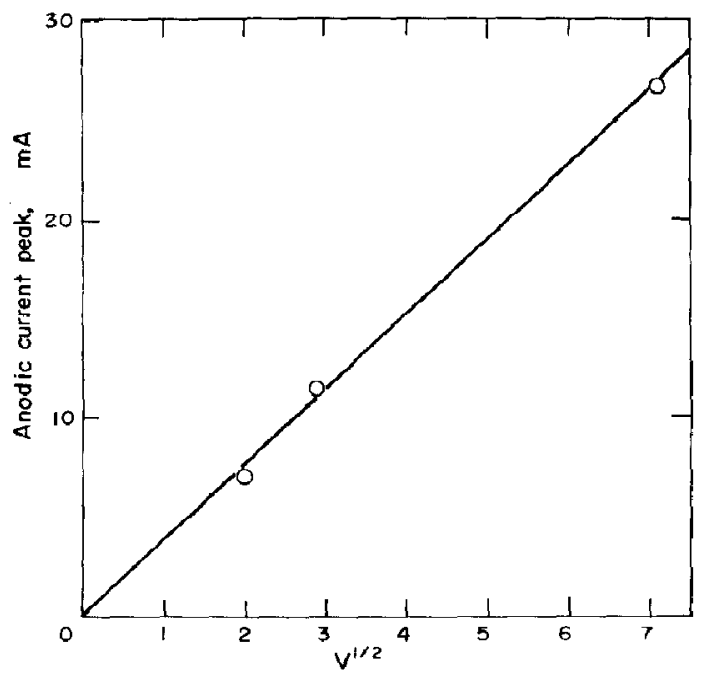

Fig. 16. Plot of the anodic current peal at $0.3 \mathrm{~V} v$ s the square root of the potential sweep rate. Graphite/nitrate melt; $245^{\circ} \mathrm{C}$.

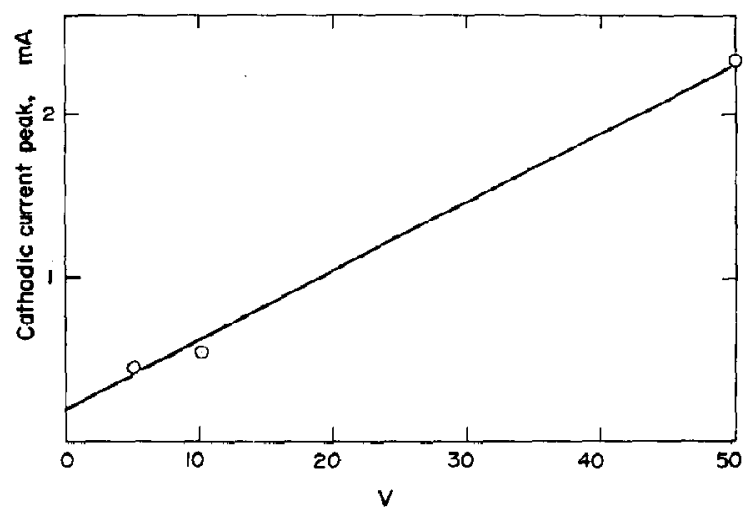

Fig. 17. Plot of the cathodic current peak at $0.225 \mathrm{~V}$ os the potentital sweep rate. Graphite/nitrate melt; $245^{\circ} \mathrm{C}$.

larly the peak current related to $\mathrm{NO}_{2}$ reduction fits the same dependence on $v$ as the $\mathrm{NO}_{2}^{-}$ion oxidation. Data shown in Fig. 19 were corrected to refer the peak height to the true baseline $(I=0)$. The apparent height of the cathodic current peak is lower than that of the anodic one.

The new oxidation peak potential becomes more anodic as $v$ increases, the shift being linear with $\log v$, as indicated in Fig. 20. The most likely slope is $0.103 \mathrm{~V} /$ decade, ie $\approx 2 \cdot 3 R T / F$. The potential of the $\mathrm{NO}_{2}^{-}$ion oxidation current peak is nearly independent of $v$ at low $\mathrm{NO}_{2}^{-}$ion concentration, but shifts towards more anodic values at the highest concentrations employed. A similar situation obtains for the $\mathrm{NO}_{2}$ reduction current peak. Here. at $l>50 \mathrm{mV} / \mathrm{s}$, the current peak is no longer distinguishable. The current peak related to the $\mathrm{OH}^{-}$ion discharge increases linearly with $v^{1 / 2}$ and the corresponding potential depends linearly on $\log v$ (Fig. 21). 


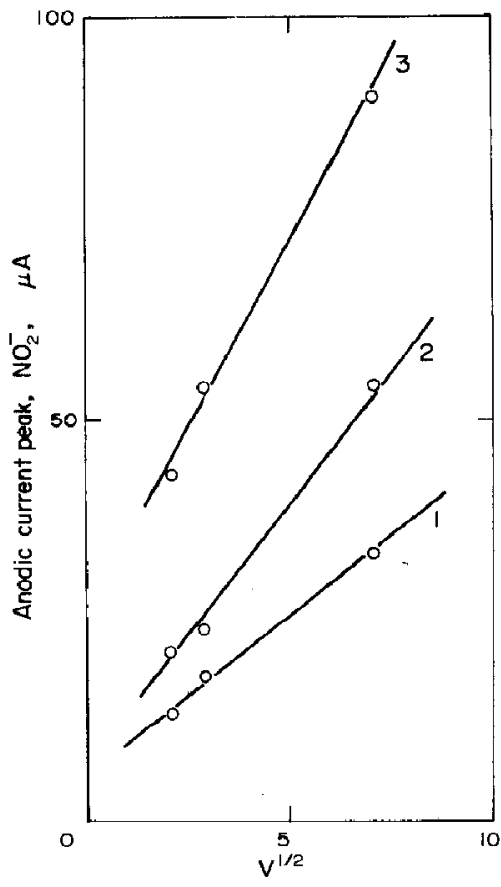

Fig. 18. Plot of the anodic nitrite current peak $r$ s the square root of the potential sweep rate, at different nitrite ion concentration. Graphite/nitrate melt; $245^{\circ} \mathrm{C}$. (1) initial concentration in the melt; (2) $5 \times 10^{-2} \mathrm{M} ;$ (3) $1.5 \times 10^{-1} \mathrm{M}$.

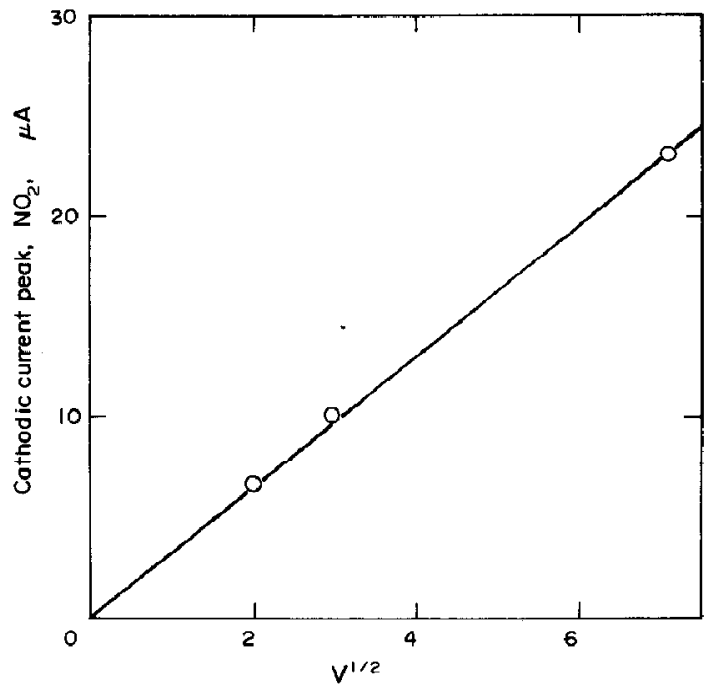

Fig. 19. Plot of the cathodic $\mathrm{NO}_{2}$ current peak vs the square root of the potential sweep rate. Graphite/nitrate melt $; 245^{\circ} \mathrm{C}$.

(ii) The platinum/molten nitrate system. In this case the height of the new oxidation current peak increases linearly with $v^{1 / 2}$ (Fig. 22) and its corresponding potential depends linearly on $\log v$ (Fig. 23). Both the anodic and cathodic peak heights of the $\mathrm{NO}_{2}^{-} / \mathrm{NO}_{2}$ couple change linearly with $v^{1 / 2}$. Finally, the height of the $\mathrm{OH}^{-}$ion oxidation pcak on platinum (Fig. 24) and its

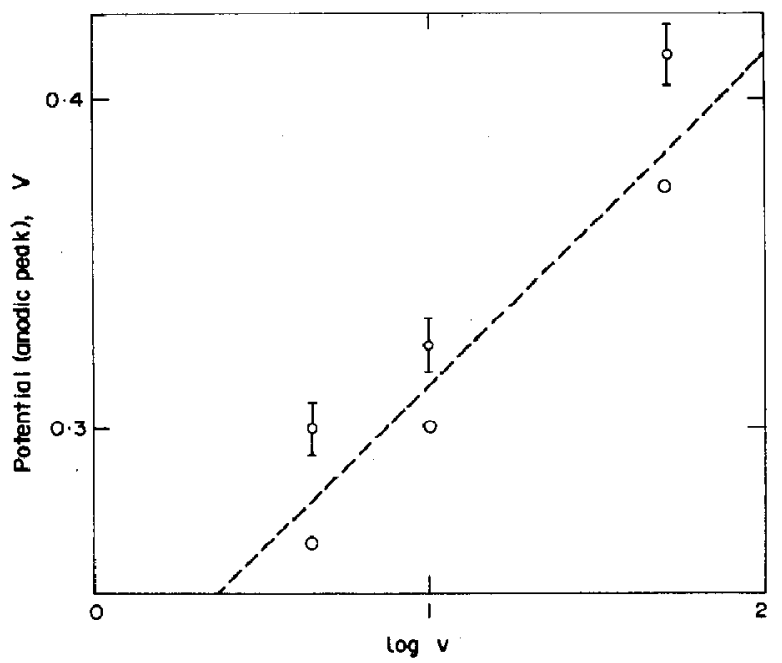

Fig. 20. Plot of the potential corresponding to anodic peak located at $c a 0.3 \mathrm{~V}$ vs $\log v$. Graphite/molten nitrate; $245^{\circ} \mathrm{C}$. The slope of the plotted line is $2 \cdot 3(R T / F)$.

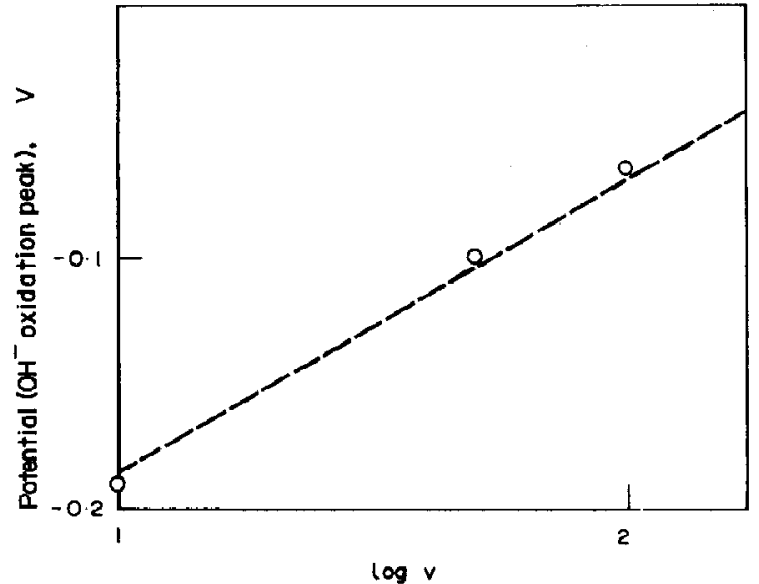

Fig, 21. Plot of the potential corresponding to the $\mathrm{OH}^{-}$ion oxidation $v$ s $\log v$. Graphite/nitrate melt $; 245^{\circ} \mathrm{C}$.

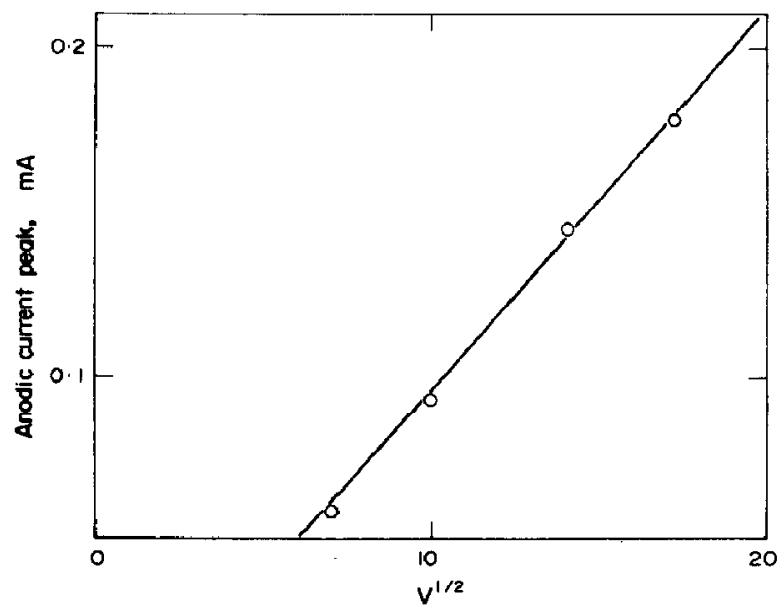

Fig. 22. Plot of the anodic current peak located at $c a 0.4-0.5 \mathrm{~V}$ us the square root of the potentital sweep rate. Platinum/ nitrate melt; $245^{\circ} \mathrm{C}$. 


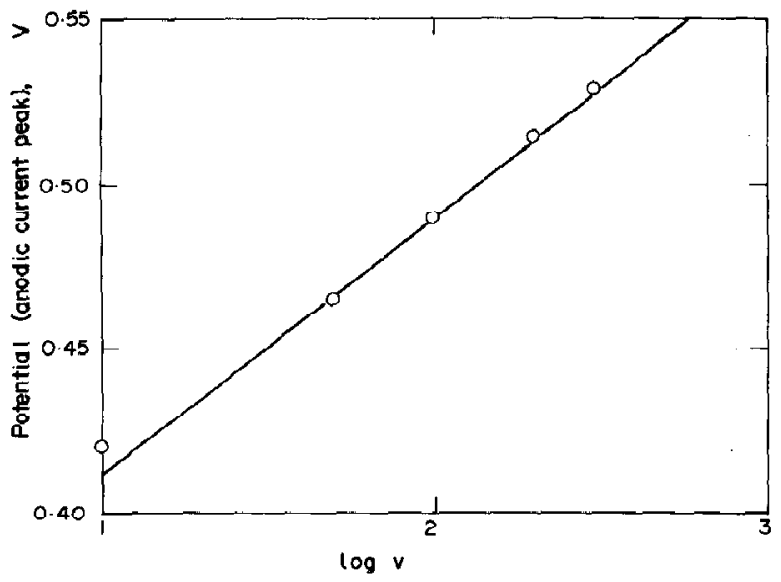

Fig. 23. Plot of the potential corresponding to the anodic peak located at $0.40 .5 \mathrm{~V}$ vs $\log v$. Platinum/molten nitrate; $244^{\circ} \mathrm{C}$.

corresponding potential fits the type of relationship just reported for the graphite electrodes.

\section{DISCUSSION}

\section{Preliminary considerations}

The thermodynamics of the nitrate/graphite system indicates there are some processes related to the spontaneous corrosion of graphite at melt temperature (Table 1). The more likely final product, as far as graphite is concerned, is carbon dioxide. The electrochemical behaviour of graphite and platinum electrodes show several coincident features. Thus, the known cur-

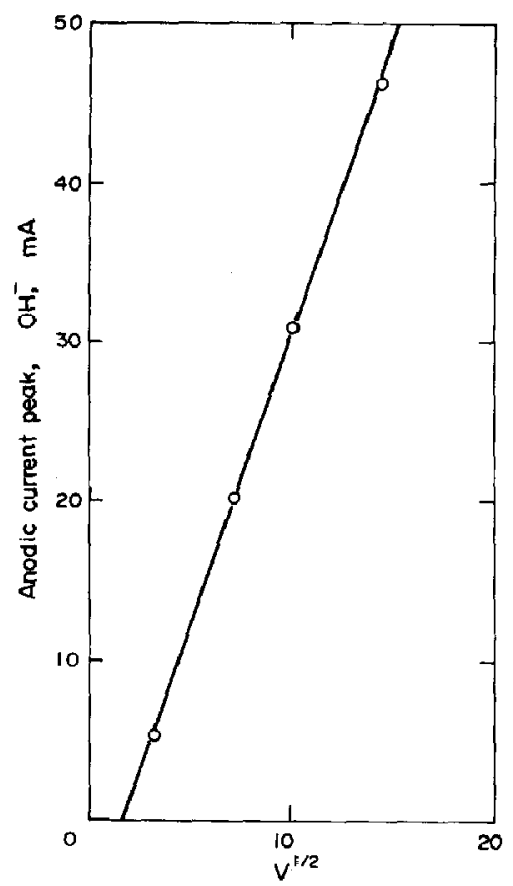

Fig. 24. Plot of the anodic current peak corresponding to the $\mathrm{OH}^{-}$ion $v s$ the square root of the potential sweep rate. Platinum/nitrate melt $; 245^{\circ} \mathrm{C}$.

rent peaks related to the $\mathrm{NO}_{2}^{-} / \mathrm{NO}_{2}, \mathrm{O}_{2}^{2-} / \mathrm{O}_{2}^{-} / \mathrm{O}_{2}$ and $\mathrm{OH}^{-} / \mathrm{O}_{2}, \mathrm{H}_{2} \mathrm{O}$ couples are observed at both electrodes and are in good agrecment with the results of Zambonin and Jordan[8]. On the other hand, the presence of a new anodic and a new cathodic current peak

Table 1. Standard free energy for different reactions at various temperatures

\begin{tabular}{|c|c|c|c|c|}
\hline & & Reaction & $\begin{array}{c}T \\
{ }^{\circ} \mathrm{K}\end{array}$ & $\begin{array}{c}\Delta G_{T}^{0} \\
\mathrm{kcal} / \mathrm{mole}\end{array}$ \\
\hline $\mathrm{C}$ (graphite) $+2 \mathrm{NaNO}_{3}(1)=$ & & $\mathrm{Na}_{2} \mathrm{O}(\mathrm{s})+\mathrm{NO}_{2}(\mathrm{~g})+\mathrm{NO}(\mathrm{g})+\mathrm{CO}_{2}(\mathrm{~g})$ & $\begin{array}{l}500 \\
600 \\
700\end{array}$ & $\begin{array}{l}(-1 \cdot 367)^{*} \\
-10.422 \\
-19.477\end{array}$ \\
\hline $3 \mathrm{C}($ graphite $)+4 \mathrm{NaNO}_{3}(1)=$ & & $2 \mathrm{Na}_{2} \mathrm{O}(\mathrm{s})+3 \mathrm{CO}_{2}(\mathrm{~g})+4 \mathrm{NO}(\mathrm{g})$ & $\begin{array}{l}500 \\
600 \\
700\end{array}$ & $\begin{array}{l}(-87.625)^{*} \\
-109.405 \\
-131.185\end{array}$ \\
\hline $\mathrm{C}($ graphite $)+\mathrm{NaNO}_{3}(\mathrm{l})=$ & $=$ & $\mathrm{NaNO}_{2}(1)+\mathrm{CO}(\mathrm{g})$ & 500 & $\begin{array}{l}(-12.612)^{*} \\
-35.467\end{array}$ \\
\hline $\mathrm{C}$ (graphite) $+2 \mathrm{NaNO}_{3}(\mathrm{l})=$ & $=$ & $2 \mathrm{NaNO}_{2}(1)+\mathrm{CO}_{2}(\mathrm{~g})$ & $\begin{array}{l}500 \\
600\end{array}$ & $\begin{array}{l}(-45 \cdot 239)^{*} \\
-86 \cdot 655\end{array}$ \\
\hline $\mathrm{C}($ graphite $)+\mathrm{NaNO}_{3}(1)=$ & $=$ & $\mathrm{CO}_{2}(\mathrm{~g})+\mathrm{NO}(\mathrm{g})+\mathrm{Na}(\mathrm{l})$ & $\begin{array}{l}500 \\
600 \\
700\end{array}$ & $\begin{array}{c}(-3.926)^{*} \\
-11.122 \\
-18.318\end{array}$ \\
\hline$C($ graphite $)+\mathrm{NaNO}_{3}(\mathrm{I})=$ & $=$ & $\mathrm{CO}(\mathrm{g})+\mathrm{NO}_{2}(\mathrm{~g})+\mathrm{Na}(\mathrm{l})$ & $\begin{array}{l}500 \\
600 \\
700\end{array}$ & $\begin{array}{c}(48.520)^{*} \\
41 \cdot 019 \\
33.518\end{array}$ \\
\hline $\mathrm{C}($ graphitc $)+\mathrm{KNO}_{3}(1)$ & $=:$ & $\mathrm{CO}_{2}(\mathrm{~g})+\mathrm{NO}(\mathrm{g})+\mathrm{K}(1)$ & $\begin{array}{l}500 \\
700\end{array}$ & $\begin{array}{l}(13 \cdot 286)^{*} \\
-11 \cdot 344\end{array}$ \\
\hline $\mathrm{C}$ (graphite) $+\mathrm{KNO}_{3}(1)$ & $=$ & $\mathrm{CO}(\mathrm{g})+\mathrm{NO}_{2}(\mathrm{~g})+\mathrm{K}(1)$ & $\begin{array}{l}500 \\
700\end{array}$ & $\begin{array}{l}(65 \cdot 743)^{*} \\
40.502\end{array}$ \\
\hline
\end{tabular}

* Extrapolated values. 
and the increase of the voltammogram area and the rest potentials, are characteristics of the graphite electrodes[1].

\section{The anion composition of the melt}

The acid base theory by Lux and Flood[9-11], can be expressed as:

$$
\mathrm{O}^{2-}+\text { acid = conjugate base, }
$$

and was applied with success to molten silicates, carbonates and phosphates. In nitrates, the following equilibria may be expected:

$$
\mathrm{NO}_{3}^{-}=\mathrm{NO}_{2}^{+}+\mathrm{O}^{2-}
$$

and

$$
2 \mathrm{NO}_{3}^{-}=2 \mathrm{NO}_{2}+\frac{1}{2} \mathrm{O}_{2}+\mathrm{O}^{2-},
$$

according to which the strong oxidising power of molten nitrates should be related to $\mathrm{NO}_{2}^{+}$or $\mathrm{NO}_{2}[7,12]$. A reaction such as (7) suggests the existence of a reversible $\mathrm{NO}_{2} / \mathrm{NO}_{2}^{+}$electrode reaction $[12,13]$

$$
\mathrm{NO}_{2}^{+}+e=\mathrm{NO}_{2}
$$

as well as that of the reversib oxygen electrode in molten nitrates, $i e[14]$

$$
\frac{1}{2} \mathrm{O}_{2}+2 e=\mathrm{O}^{2-} \text {. }
$$

However, the pertinent equilibrium appears to involve a single electron transfer $[15,16]$,

$$
\mathrm{NO}_{3}^{-}=\mathrm{NO}_{2}+\frac{1}{2} \mathrm{O}_{2}+e
$$

which corresponds to the reversible nitrate electrode in the molten nitrate. Now, with presence of either water of $\mathrm{OH}^{-}$ion the following reaction is postulated[17]:

$$
4 \mathrm{OH}^{-}=\mathrm{O}_{2}+2 \mathrm{H}_{2} \mathrm{O}+4 e .
$$

Reactions (10) and (12) are related to the equilibrium:

$$
\mathrm{O}^{2-}+\mathrm{H}_{2} \mathrm{O}=2 \mathrm{OH}^{-} \text {. }
$$

The values reported for the equilibrium constant of reaction (13) cover the range from nearly infinity[17] down to approximately zero[18].

More recently the oxidation of $\mathrm{O}^{2-}$ ion has been interpreted with the following reaction:

$$
2 \mathrm{O}^{2-}=\mathrm{O}_{2}^{2-}+2 e,
$$

and Zambonin and Jordan $[8,19,22]$ propose the existence of the following related equilibria:

$$
\begin{aligned}
\mathrm{NO}_{3}^{-}+\mathrm{O}^{2-} & =\mathrm{NO}_{2}^{-}+\mathrm{O}_{2}^{2-} \\
2 \mathrm{NO}_{3}^{-}+\mathrm{O}_{2} & =2 \mathrm{NO}_{2}^{-}+2 \mathrm{O}_{2}^{-} \\
2 \mathrm{O}_{2}^{-} & =\mathrm{O}_{2}^{2-}+\mathrm{O}_{2}
\end{aligned}
$$

and

$$
3 \mathrm{O}_{2}^{2-}=2 \mathrm{O}_{2}^{-}+2 \mathrm{O}^{2-},
$$

and the predominant oxygen electrode reaction in nitrate melt is

$$
\mathrm{O}_{2}^{-}=\mathrm{O}_{2}+e \text {. }
$$

The existence of the three oxygen ions would explain the voltammetric and chronopotentiometric behaviour of molten nitrates, either in solutions containing acids $\left(\mathrm{S}_{2} \mathrm{O}_{7}^{2-}, \mathrm{HSO}_{4}^{-}, \mathrm{NO}_{2}\right)$ or in solutions containing bases $\left(\mathrm{NO}_{2}^{-}, \mathrm{NO}, \mathrm{CO}_{3}^{2-}, \mathrm{O}^{2-}, \mathrm{OH}^{-}, \mathrm{O}_{2}^{-}\right)$, without the presence of the $\mathrm{NO}_{2}^{+}$ion[7]. The addition of a strong acid to the molten nitrate produces an effect similar to $\mathrm{NO}_{2}$, which can be reduced in a single electron transfer reaction, but cannot be electrochemically oxidised[7]. The presence of nitrite initially in the nitrate melt has been evidenced[23] and it should be a consequence of equilibria (15)-(18), involving the different oxygen ions.

On the other hand, Shams El Din and El Hosary $[24,25]$ showed that $\mathrm{O}_{2}^{-}, \mathrm{OH}^{-}$or electrogenerated $\mathrm{O}^{2-}$ ions react with the nitratc molt yiclding pyronitrate.

\section{The anodic oxidation of nitrate ion}

It is clear that the electrochemical oxidation of $\mathrm{NO}_{3}^{-}$ ion, on graphite as well as on platinum, occurs at an appreciable rate at the highest potentials and is at least preceded by four other reactions. In both cases no anodic current peak has been observed for the $\mathrm{NO}_{3}^{-}$ion oxidation, but the current increases exponentially with potential.

Kinetic data available from previous work allow the calculation of the stationary current-potential curves for the anodic discharge of $\mathrm{NO}_{3}^{-}$ion. On platinum $[26,27]$ as well as on graphite electrodes, their Tafel slope is equal to $2 R T / F$ at $250^{\circ} \mathrm{C}$ characterising thus an activated electrochemical process. The final products for the former are $\mathrm{NO}_{2}$ and $\mathrm{O}_{2}$ while for the latter they are carbon oxides and nitrogen oxides $[1,2]$.

The kinetics of this reaction on platinum changes with temperature as seen by values of the Tafel slope which goes from $2 R T / F$ at $250^{\circ} \mathrm{C}$ to $R T / F$ at $350^{\circ} \mathrm{C}[1,27]$. At lower temperatures the main anodic reaction on graphite is:

$$
\mathrm{C}+2 \mathrm{NO}_{3}^{-}=2 \mathrm{NO}_{2}+\mathrm{CO}_{2}+2 e
$$

and the postulated mechanism for this reaction is:

$$
\begin{gathered}
\mathrm{C}+\mathrm{NO}_{3}^{-}=\left(\mathrm{NO}_{3}\right) \mathrm{C}+e \\
\left(\mathrm{NO}_{3}\right) \mathrm{C}=(\mathrm{O}) \mathrm{C}+\mathrm{NO}_{2} \\
(\mathrm{O}) \mathrm{C}+\mathrm{NO}_{3}^{-}=\mathrm{NO}_{2}+\mathrm{CO}_{2}+e
\end{gathered}
$$

where $(20 \mathrm{c})$ is the rate-determining step under conditions of a high degree of surface oxidation. The rate equation in terms of current density, $i$, is:

$$
i=z F k_{u} a_{\mathrm{NO}_{z}} \exp (\alpha \eta F / R T),
$$

where $k_{a}$ is the specific rate constant of step (20c); $a_{\mathrm{NO}_{5}}$ is the nitrate ion activity at the interface, $\alpha$ is the transfer coefficient of the anodic reaction $(\alpha=0.5)$ and the rest of symbols have their usual meaning.

At higher temperatures the situation is somewhat different. The primary step is still the $\mathrm{NO}_{3}^{-}$ion dis- 
charge, but the reaction mechanism changes according to:

$$
\begin{aligned}
\mathrm{NO}_{3}^{-}+\mathrm{C} & =\left(\mathrm{NO}_{3}\right) \mathrm{C}+e \\
\left(\mathrm{NO}_{3}\right) \mathrm{C} & =\mathrm{NO}+\mathrm{CO}_{2}
\end{aligned}
$$

or

$$
\begin{gathered}
\mathrm{NO}_{3}^{-}+\mathrm{C}=\mathrm{NO}_{2}+(\mathrm{O}) \mathrm{C}+e \\
\mathrm{NO}_{2}+(\mathrm{O}) \mathrm{C}=\mathrm{NO}+\mathrm{CO}_{2} .
\end{gathered}
$$

Reaction schemes (22) and (23) involve charge transfer and thermal steps. Both mechanisms present alternative rate determining steps. It is unlikely that the energetics of the reaction rate would be mainly related to the thermal steps, as deduced from thermodynamic data given in Table 2. Furthermore, if they were significant rate limiting reactions no simple explanation could be advanced for the high anodic Tafel slope above mentioned. Therefore, only reactions (22a) or (23a) should be considered as rate determining and the anodic current density becomes:

$$
i={ }_{z} F k_{a} a_{\mathrm{NO}_{3}^{-}} a_{\mathrm{c}} \exp (\alpha \eta F / R T),
$$

where $a_{\mathrm{C}}$ is the activity of the electrode surface. Taking again $\alpha=0.5$, the anodic Tafel slope is $2 R T / F$ as found in the stationary runs. From the kinetic viewpoint, at present both reactions (22a) and (23a) appear as indistinguishable steps.

At low temperature, on platinum, the total anodic reaction is:

$$
2 \mathrm{NO}_{3}^{-}=2 \mathrm{NO}_{2}+\mathrm{O}_{2}+2 e
$$

and the mechanism of the reaction is $[15,27]$ :

$$
\begin{gathered}
\mathrm{NO}_{3}^{-}+\mathrm{Pt}=\left(\mathrm{NO}_{3}\right) \mathrm{Pt}+e \\
\left(\mathrm{NO}_{3}\right) \mathrm{Pt}=(\mathrm{O}) \mathrm{Pt}+\mathrm{NO}_{2} \\
\mathrm{Pt}(\mathrm{O})+\mathrm{Pt}(\mathrm{O})=\mathrm{O}_{2}+2 \mathrm{Pt} \\
\mathrm{Pt}(\mathrm{O})+\mathrm{NO}_{3}^{-}=\mathrm{NO}_{2}+\mathrm{O}_{2}+\mathrm{Pt}+e
\end{gathered}
$$

where reaction (26a) is the rate determining step. The corresponding rate equation becomes:

$$
i=z F k_{a} a_{\mathrm{NO}_{3}} a_{\mathrm{C}} \exp (\eta F / 2 R T) \text {. }
$$

Another interpretation of the reaction was advanced by Gupta and Sundheim[28] as follows:

$$
\begin{gathered}
\mathrm{NO}_{3}^{-}=\mathrm{NO}_{2}^{+}+\mathrm{O}^{2-} \\
\mathrm{O}^{2-}=\mathrm{O}+2 \mathrm{e} \\
\mathrm{O}+\mathrm{O}=\mathrm{O}_{2} \\
\mathrm{NO}_{2}^{+}+\mathrm{NO}_{3}^{-}=\left(\mathrm{N}_{2} \mathrm{O}_{5}\right)=2 \mathrm{NO}_{2}+\frac{1}{2} \mathrm{O}_{2}
\end{gathered}
$$

where the $\mathrm{O}^{2-}$ ion would be solvated as the orthonitrate ion:

$$
\mathrm{NO}_{3}^{-}+\mathrm{O}^{2-}=\mathrm{NO}_{4}^{3-} \text {. }
$$

At high temperatures the Tafel slope approaches the ratio $R T / F$. The reaction was tentatively interpreted assuming the initial discharge of $\mathrm{O}^{2-}$ ion. The corresponding rate cquation is:

$$
i=z F k^{\prime} \exp (\eta F / R T),
$$

where $k^{\prime}$ is a complex rate constant. The previous mechanisms should be modified now on the basis that species such as $\mathrm{O}_{2}^{-}$and $\mathrm{O}_{2}^{2-}$ ions predominate over $\mathrm{O}^{2-}$ ion in the nitrate melt and it may probably comprise the $\mathrm{NO}_{3}^{-}$ion discharge through the equilibria involving the various oxygen anions, and obeying a Temkin-type adsorption isotherm.

\section{The oxidation of the nitrite ion}

Nitrite ions exist in the nitrate melt and participate in various ionic equilibria[5,29-31]. Either with graphite or platinum electrodes its discharge occurs at a potential lower than that of the nitrate ion oxidation. As suggested by Lyalikov[32], the nitrite electrode diluted in alkaline nitrate melt, under certain conditions behaves as a reversible system.

On platinum, when the nitrite concentration increases[5], the activated process becomes more sluggish and under steady state conditions the $E-I$ curve yields a Tafel line with a slope of $R T / F$ within the temperature range $200-400^{\circ} \mathrm{C}[33,34]$. The following mechanism was put forward to explain these results:

$$
\begin{aligned}
& \mathrm{NO}_{2}^{-}+\mathrm{Pt}=\left(\mathrm{NO}_{2}\right) \mathrm{Pt}+e \\
&(\mathrm{NO}) \mathrm{Pt}=\mathrm{NO}_{2}+\mathrm{Pt} \\
& 2\left(\mathrm{NO}_{2}\right) \mathrm{Pt}=\mathrm{N}_{2} \mathrm{O}_{4}+2 \mathrm{Pt} \\
&\left(\mathrm{N}_{2} \mathrm{O}_{4}\right.\left.=2 \mathrm{NO}_{2}\right) \\
& \mathrm{NO}_{2}^{-}+\mathrm{NO}_{2}=\mathrm{NO}+\mathrm{NO}_{3}^{-} \\
&\left(\mathrm{NO}+\mathrm{NO}_{2}=\mathrm{N}_{2} \mathrm{O}_{3}\right)
\end{aligned}
$$

where step ( $3 \mathrm{lb}$ ) is rate determining, under a low degree of surface coverage by the $\left(\mathrm{NO}_{2}\right)$ intermediate. The rate equation derived from this reaction scheme is:

$$
i=z F k_{b} K_{a} a_{\mathrm{NO}_{2}^{-}} \exp (\eta F / R T)
$$

where $K_{a}=\left(k_{a} / k_{-a}\right)$.

The nitrite ion oxidation on graphite in the temperature range $245-340^{\circ} \mathrm{C}$ yields $\mathrm{NO}_{2}$. The process is characterised by a Tafel slope equal to $2 R T / 3 F$ which was interpreted with the following reaction scheme:

$$
\begin{aligned}
\mathrm{NO}_{2}^{-}+\mathrm{C} & =\left(\mathrm{NO}_{2}\right) \mathrm{C}+e \\
\mathrm{NO}_{2}^{-}+\left(\mathrm{NO}_{2}\right) \mathrm{C} & =\left(\mathrm{N}_{2} \mathrm{O}_{4}\right)+\mathrm{C}+e \\
\left(\mathrm{~N}_{2} \mathrm{O}_{4}\right. & \left.=2 \mathrm{NO}_{2}\right) \\
\mathrm{NO}_{2}^{-}+\mathrm{NO}_{2} & =\mathrm{NO}+\mathrm{NO}_{3}^{-} \\
\left(\mathrm{NO}+\mathrm{NO}_{2}\right. & \left.=\mathrm{N}_{2} \mathrm{O}_{3}\right)
\end{aligned}
$$

reaction (33b) being the rate determining step. The rate equation is:

$$
i=z F k_{h} a_{C} a_{\mathrm{No}}, \exp (3 \eta F / 2 R T) \text {. }
$$

As the concentration of nitrite in the nitrate melt is small its oxidation might be expected to be diffusion controlled and indeed the observed current peak is expressed by the usual relationship:

$$
i=z F C_{\mathrm{NO}_{2}^{-}}\left(\pi D_{\mathrm{NO}_{2}^{-}} a\right)^{1 / 2} \chi(\mathrm{at}),
$$

$a=z F v / R T: D_{\mathrm{NO}_{2}}$ is the diffusion coefficient of nitrate ion and $\chi(\mathrm{at})$ is a function of the potential which is tabulated[35]. The observed peak height was cor- 
Table 2. Standard free energy change of different reactions involving $\mathbf{N O}_{2}$

\begin{tabular}{|c|c|c|c|c|}
\hline \multicolumn{3}{|c|}{ Reaction } & $\begin{array}{c}T \\
{ }^{\circ} \mathbf{K}\end{array}$ & $\begin{array}{c}\Delta G_{T}^{0} \\
\mathrm{kcal} / \mathrm{mole}\end{array}$ \\
\hline $\mathrm{CO}(\mathrm{g})+\mathrm{NO}_{2}(\mathrm{~g})$ & $=$ & $\mathrm{NO}(\mathrm{g})+\mathrm{CO}_{2}(\mathrm{~g})$ & $\begin{array}{l}500 \\
600 \\
700\end{array}$ & $\begin{array}{l}-52 \cdot 457 \\
-52 \cdot 141 \\
-51 \cdot 836\end{array}$ \\
\hline $2 \mathrm{NO}_{2}(\mathrm{~g})+\mathrm{C}($ graphite $)$ & $=$ & $\mathrm{CO}_{2}(\mathrm{~g})+2 \mathrm{NO}(\mathrm{g})$ & $\begin{array}{l}500 \\
600 \\
700\end{array}$ & $\begin{array}{l}-84.899 \\
-88.561 \\
-92.231\end{array}$ \\
\hline $\mathrm{NO}_{2}(\mathrm{~g})+\mathrm{C}$ (graphite) & $=$ & $\mathrm{NO}(\mathrm{g})+\mathrm{CO}(\mathrm{gas})$ & $\begin{array}{l}500 \\
600 \\
700\end{array}$ & $\begin{array}{l}-32 \cdot 442 \\
-36.444 \\
-40.395\end{array}$ \\
\hline
\end{tabular}

rected for the residual current on both sides of the peak potential.

\section{The cathodic reduction of nitrate ion}

The electrolysis at $250^{\circ} \mathrm{C}$ of the scrupulously dried melt at high cathodic potentials lead to $\mathrm{O}_{2}^{-}$and $\mathrm{NO}_{2}^{-}$ ions but if the melt contains water, then $\mathrm{OH}^{-}$and $\mathrm{NO}_{2}^{-}$ions are the reaction products. All these species were properly identified in the voltammograms.

Various authors advanced mechanistic interpretations for the electrochemical reduction of nitrate in melt. Hills and Johnston[36] recorded cathodic polarograms using $\mathrm{NaNO}_{3}-\mathrm{KNO}_{3}$ melt on platinum microelectrodes at 280 and $400^{\circ} \mathrm{C}$. A sharp reduction peak was observed as $c a-1.5 \mathrm{~V}$, with respect to a platinum electrode of large area, followed by an abrupt current increase at $\mathrm{ca}-3.0 \mathrm{~V}$. This fact is in agreement with the discharge of alkaline metals in molten alkaline nitrates earlier reported $[37,38]$, and with the reactions

$$
\mathrm{NO}_{3}^{-}+2 e=\mathrm{NO}_{2}^{-}+\mathrm{O}^{2-}
$$

or

$$
\mathrm{NO}_{3}^{-}+e=\mathrm{NO}_{2}+\mathrm{O}^{2-} \text {. }
$$

The process is irreversible and this agrees with the interpretation of Bartlett and Johnston[39]. Swofford and Laitinen[40] investigated the matter further and concluded that $\mathrm{NO}_{3}^{-}$ion reduction on platinum and other microelectrodes is limited by the $\mathrm{Na}_{2} \mathrm{O}$ precipitation on the electrode surface.

Although it should be noted that the $\mathrm{O}^{2-}$ ion is normally not present in the melt $[19,20,41]$, the reduction of $\mathrm{NO}_{3}^{-}$ion will, therefore, produce species such as $\mathrm{O}_{2}^{2-}, \mathrm{O}_{2}^{-}$and $\mathrm{NO}_{2}^{-}$. The $\mathrm{O}_{2}^{2-}$ ion concentration decreasing with time, while the $\mathrm{O}_{2}^{-}$and $\mathrm{NO}_{2}^{-}$ion concentrations increase. The reaction

$$
\mathrm{O}_{2}^{2-}+2 \mathrm{NO}_{2}=2 \mathrm{NO}_{3}^{-}
$$

produces a "hidden limiting current" which make difficult the straightforward determination of $\mathrm{NO}_{2}^{-}$ion reduction limiting current. This can be understood in terms of the electrochemical reaction involving $\mathrm{O}_{2}^{-}$ and NO, and also the equilibrium:

$$
\mathrm{O}_{2}^{2-}+2 \mathrm{NO}_{3}^{-}=2 \mathrm{O}_{2}^{-}+2 \mathrm{NO}_{2}^{-}
$$

for which the equilibrium constant at $229^{\circ} \mathrm{C}$, is $6.7 \times 10^{-11}$.

The mechanism postulated by Zambonin for the $\mathrm{NO}_{3}^{-}$ion reduction can be summarised as follows[6]:

$$
\begin{aligned}
\mathrm{NO}_{3}+2 e & =\mathrm{NO}_{3}^{3-} \\
\mathrm{NO}_{3}^{3-} & =\mathrm{NO}_{2}^{-}+\mathrm{O}^{2-}(\mathrm{sol}) \\
\mathrm{O}^{2-}+2 \mathrm{Na}^{+} & =\mathrm{Na}_{2} \mathrm{O} \text { (insol) }
\end{aligned}
$$

The accumulation of $\mathrm{Na}_{2} \mathrm{O}$ at the interface inhibits a further reduction of the $\mathrm{NO}_{3}^{-}$ion. The equilibrium of the different oxygen ions has been omitted in the reaction mechanism. Nitrate melts containing water react according to:

$$
\mathrm{NO}_{3}^{-}+\mathrm{H}_{2} \mathrm{O}+2 e=\mathrm{NO}_{2}^{-}+2 \mathrm{OH}^{-} \text {. }
$$

\section{Oxide formation and reduction at the electrode sur-} face

The anodic current peak found between 0.25 and $0.35 \mathrm{~V}$, with both platinum and graphite electrodes, increases with the square root of $v$, and the dependence of its potential on $v$ fits the equation for an irreversible process under diffusion control The slope of the potential at current peak $v s \log v$, is $R T / F$ for both graphite and platinum, yielding an $\alpha z_{a}$ value equal to 0.5 , where $z_{a}$ is the number of electrons used up to the rate determining step[35]. The relevant fact is the occurrence of the peak only when $\mathrm{NO}$ and $\mathrm{O}_{2}^{-}$ion are simultaneously present and for graphite only, its occurrence implies the existence of a new reduction current peak.

The surface oxide may be formed during the anodic discharge of $\mathrm{NO}_{3}^{-}$ion where the main oxidising species must be the $\mathrm{NO}_{3}$ radical. which acts as intermediate both on graphite as well as platinum. The final products. however, are different, ie, while graphite corrodes, platinum is unchanged. Thus, only for graphite the reduction current peak is observed. The corresponding reaction can be written as follows:

$$
\mathrm{C}(\mathrm{O})+2 e=\mathrm{C}+\mathrm{O}^{2-}
$$

or better suited to the melt composition recently suggested:

$$
2 \mathrm{C}(\mathrm{O})+e=2 \mathrm{C}+\mathrm{O}_{2}^{-} .
$$


Based on the preceden tfacts, the probable reaction pathways for graphite are stated as follows:

Oxidation:

$$
\begin{aligned}
\mathrm{C}+\mathrm{NO}+\mathrm{O}_{2}^{-} & =\left(\mathrm{NO}_{3}\right) \mathrm{C}+e \\
\left(\mathrm{NO}_{3}\right) \mathrm{C} & =(\mathrm{O}) \mathrm{C}+\mathrm{NO}_{2}
\end{aligned}
$$

Reduction:

$$
2 \mathrm{C}(\mathrm{O})+e=2 \mathrm{C}+\mathrm{O}^{-}
$$

or

$$
\begin{aligned}
\mathrm{C}(\mathrm{O})+2 e & =\mathrm{C}+\mathrm{O}^{2-} \\
\mathrm{O}^{2-}+\mathrm{NO}_{3}^{-} & =\mathrm{NO}_{2}^{-}+\mathrm{O}_{2}^{2-} \\
\mathrm{O}_{2}^{2-}+2 \mathrm{NO}_{3}^{-} & =2 \mathrm{O}_{2}^{-}+2 \mathrm{NO}_{2}^{-}
\end{aligned}
$$

and for platinum electrodes:

Oxidation:

$$
\begin{gathered}
\mathrm{Pt}(\mathrm{O})+\mathrm{NO}+\mathrm{O}_{2}^{-}=\mathrm{PtO}\left(\mathrm{NO}_{3}\right)+e \\
2 \mathrm{PtO}\left(\mathrm{NO}_{3}\right)=2 \mathrm{Pt}(\mathrm{O})+2 \mathrm{NO}_{2}+\mathrm{O}_{2}
\end{gathered}
$$

The reduction of platinum surface oxide, if any, in the absence of oxidising species, would occur probably at more cathodic potentials.

The reduction current peak potential exhibits no measurable shift with the potential sweep rate. Its height depends approximately linear on the potential sweep rate. This suggested the reduction process is irreversible, a fact which resembles the characteristics of platinum oxide reduction in aqueous solutions [41,42] as well as in acid bisulphate melts [43]. As in these cases it is likely that in the present circumstances the electrochemical process yielding $\mathrm{O}_{2}^{-}$ion is also a second order irreversible process. Unfortunately, the voltammogram in this potential region is too complex to allow further conclusions on the reaction pathway.

\section{The electrochemical oxidation of hydroxyl ion}

The reduction of $\mathrm{NO}_{3}^{-}$ion in the presence of water yields $\mathrm{OH}^{-}$ions, both on graphite and platinum electrodes. The height of the corresponding current peak depends on $v^{1 / 2}$ and its potential changes linearly with $\log v$, with a slope of $R T / F$. Its rate is probably determined by an initial irreversible single electron transfer step which is followed by a chemical reaction, such as,

$$
\begin{aligned}
\mathrm{C}+\mathrm{OH}^{-} & =\mathrm{C}(\mathrm{OH})+e \\
2 \mathrm{C}(\mathrm{OH}) & =\mathrm{H}_{2} \mathrm{O}+\mathrm{C}(\mathrm{O})+\mathrm{C} \\
2 \mathrm{C}(\mathrm{O}) & =\mathrm{CO}_{2}+\mathrm{C} .
\end{aligned}
$$

The first step comprises the $\mathrm{OH}^{-}$ion discharge and the $\mathrm{OH}$ radical adsorption. A comparable adsorption process is known to occur for the thermal adsorption of water on graphite[44]. If this step is rate-determining, the rate equation, on the assumption that its symmetry factor is 0.5 , is

$$
i=z F k_{a} a_{\mathrm{C}} a_{\mathrm{OH}^{-}} \exp (\eta F / 2 R T) .
$$

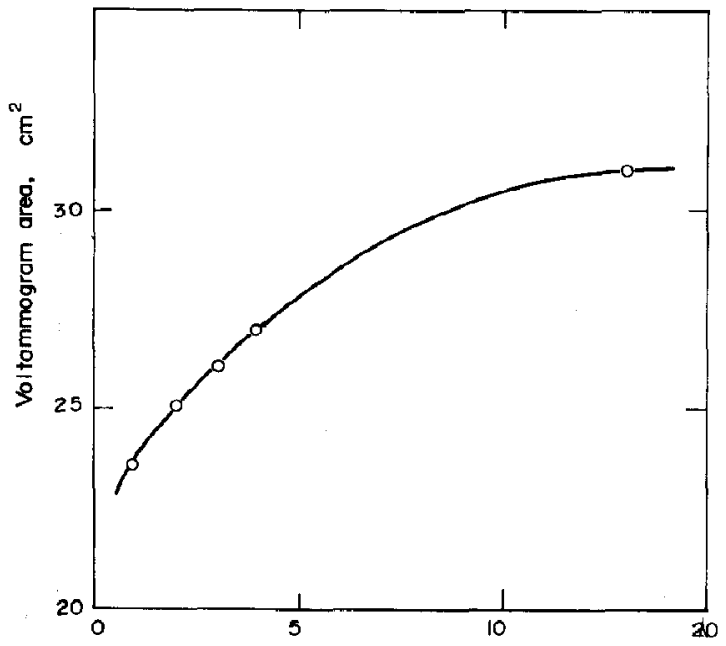

Fig. 25. Plot of the voltammogra marea against the nu mber of repetitive potential sweeps.

This equation fits the results reasonable well as will be seen further on. Furthermore, this reaction scheme resembles the one recently discussed for the reduction of $\mathrm{OH}^{-}$ion in nitrate melts on platinum[45].

\section{The increase of the graphite electrode area}

The increase of the voltammogram area during repetitive potential cycling within the potential range where the oxidation occurs, is a consequence of the corrosion of graphite in the nitrate melt. The area increase depends on the amount of charge passed, but as seen in Fig. 25, the area increases up to a limiting value which is about 1.5 times the initial electrode area. This factor may represent the roughness of the electrode acquired during stationary experiments and should be taken into account in defining the corrosion current densities.

\section{The graphite rest potential}

The rest potential for thermally treated graphite electrodes is $0 \cdot 1-0 \cdot 2 \mathrm{~V}$, but for electrodes used without any special treatment, the initial rest potential is between $-0 \cdot 1$ to $-0 \cdot 2 \mathrm{~V}$. With increasing temperature the electrode rest potential becomes more negative. This effect which is also observed with platinum, is irreversible.

The addition of basic species also makes the rest potential more negative, while the addition of acid species has the reverse effect. Therefore, the increase of the temperature is equivalent to an increase of the concen tration of basic species in the melt. The corrosion of graphite itself may contribute for the formation of basic ions, as seen in Fig. 15. Certainly the rest potentials of either graphite or platinum dipped in to the melt at high temperature decrease when a graphite rod is placed in contact with the melt. 
10 Correlation between chemical and electrochemical behaviour of graphite

The electrochemical behaviour of graphite is to a large extent related to its thermal oxidation in the temperature range studied here. At $200^{\circ} \mathrm{C}$ or even lower temperatures oxygen reacts with activated carbons through steps of irreversible adsorption and desorption, yielding as final product either $\mathrm{CO}$ or $\mathrm{CO}_{2}$ [46]. At least two functional type of sites exist on carbons, each being related respectively to the desorption as $\mathrm{CO}$ and $\mathrm{CO},[47-51]$. Carbons treated at $T<500^{\circ} \mathrm{C}$ exhibit acidic properties, while those treated at higher temperatures are considered as basic. The surface oxides accumulate at lower temperatures, but their thermal stability depends strongly on the nature of carbons [52-55]. Reviews about these works up to recent years are respectively given in references [56-59], including the various mechanisms proposed for the gasification of carbons[60-66]. An appreciable difference of kinetic behaviour between monolayer and multilayer graphite surface oxides has been observed[67,70]. During the oxidation process of graphite an intermediate mobile surface oxide, before $\mathrm{CO}_{2}$ evolution, was postulated [71-73] and in the thermal oxidation by means of strong oxidising agents, such as ozone, a transient surface oxide has been proposed. From the point of view of this report it should also be mentioned that NO adsorbs irreversibly on fresh graphite surfaces yielding a (NO)C adsorbed species[74]. The amount adsorbed decreases on oxidised graphite surface. Water also adsorbs on graphite $[44,72]$.

The electrochemical oxidation of graphite occurs in aqueous electrolytes[76-85] as well as in other molten electrolytes containing oxo-anions[3,86-89]. Most of the work done referred to either carbon or graphite electrodes used in aluminium production cells and all this information leads to a better understanding of the electrochemical behaviour of graphite.

The corrosion of graphite occurring during the electrochemical oxidation of $\mathrm{NO}_{3}^{-}$ion was explained through the participation of the $\mathrm{NO}_{3}$ intermediate, the final reaction products depending on the temperature. A comparable situation probably arises when the discharge of the $\mathrm{O}_{2}^{-}$ion in the presence of NO takes place. One can think that NO acts as a radical scavenger assisting the graphite oxidation through $\mathrm{NO}_{3}$ formation, by keeping a high surface concentration of $\mathrm{C}(\mathrm{O})$ groups. Hence, any hinderance in $\mathrm{NO}_{3}$ formation, either by the absence of $\mathrm{O}_{2}^{-}$ion or NO molecules must supress the graphite corrosion process. The electronic structure of $\mathrm{O}_{2}^{-}$ion, $\mathrm{NO}$ and graphite are favourable to the formation of an intermediate such as $\mathrm{NO}_{3}$ at the graphite surface. Then, the final reaction products will be determined principally by the concentration of strongly oxidising species in the melt. Thus, the temperature effect, as far as the final reaction products is concerned, can be understood.

The formation of $\mathrm{NO}_{3}$ requires the initial electrochemical oxidation of one of the following species: $\mathrm{O}_{2}^{-}$ ion, NO or graphite at the surface. Therefore, three possibilities arise for the initiation of graphite corrosion in the nitrate melts:

Mechanism I:

$$
\begin{aligned}
\mathrm{O}_{2}^{-}+\mathrm{C} & =\left(\mathrm{O}_{2}\right) \mathrm{C}+e \\
\left(\mathrm{O}_{2}\right) \mathrm{C}+\mathrm{NO} & =\left(\mathrm{NO}_{3}\right) \mathrm{C}
\end{aligned}
$$

Mechanism II:

$$
\begin{aligned}
\mathrm{NO}+\mathrm{C} & =\left(\mathrm{NO}^{+}\right) \mathrm{C}+e \\
\left(\mathrm{NO}^{+}\right) \mathrm{C}+\mathrm{O}_{2}^{-} & =\left(\mathrm{NO}_{3}\right) \mathrm{C}
\end{aligned}
$$

Mechanism III:

$$
\begin{aligned}
\mathrm{C} & =\mathrm{C}^{+}+e \\
\mathrm{C}^{+}+\mathrm{O}_{2}^{-} & =\mathrm{C}\left(\mathrm{O}_{2}\right) \\
\left.\mathrm{C}_{2} \mathrm{O}_{2}\right)+\mathrm{NO} & =\left(\mathrm{NO}_{3}\right) \mathrm{C}
\end{aligned}
$$

and the following steps are:

$$
\begin{aligned}
\left(\mathrm{NO}_{3}\right) \mathrm{C} & =\mathrm{NO}_{2}+(\mathrm{O}) \mathrm{C} \\
2(\mathrm{O}) \mathrm{C} & =\mathrm{C}+\mathrm{CO}_{2} \\
\left(\mathrm{NO}_{3}\right) \mathrm{C} & =\mathrm{NO}+\mathrm{CO}_{2} \\
\left(\mathrm{CO}_{2}+\mathrm{C}\right. & =2 \mathrm{CO})
\end{aligned}
$$

The contribution of step (51f) becomes more significant when the temperature is increased. Equilibria comprising nitrogen oxides, such as (33c) and (33e) also participate in the reaction schemes. Any of these reaction schemes lead to the Tafel slope equal to $2 R T / F$ as found through the different relationships between the experimental parameters derived from the voltammograms, if the initial electron transfer step is rate determining.

The anodic peak due to the $\mathrm{O}_{2}^{-}$ion $+\mathrm{NO}$ reaction on platinum can be explained in terms of a mechanism resembling initially mechanism $I$, but involving a different fate for the reaction in termediate:

$$
\begin{aligned}
\mathrm{O}_{2}^{-}+\mathrm{Pt} & =\left(\mathrm{O}_{2}\right) \mathrm{Pt}+e \\
\left(\mathrm{O}_{2}\right) \mathrm{Pt}+\mathrm{NO} & =\left(\mathrm{NO}_{3}\right) \mathrm{Pt} \\
\mathrm{Pt}\left(\mathrm{NO}_{3}\right) & =\mathrm{Pt}+\frac{1}{2} \mathrm{O}_{2}+\mathrm{NO}_{2}
\end{aligned}
$$

where again the initial electron transfer step is rate-determining.

\section{Reconstruction of the anodic voltammogram}

On the bases of the individual electrochemical reactions just discussed one can attempt to build up a whole anodic voltammogram. For the purpose it is convenient to proceed from one of the extremes, either anodic or cathodic. Calculations start with the aid of equations (21), (24), (27) and (30), the E-I voltammogram related to the $\mathrm{NO}_{3}^{-}$ion oxidation can be easily drawn, both for platinum and graphite. Another possibility consists in obtaining each voltammogram in. dependently starting from the low anodic potential region. Then, at potentials beyond $0.7 \mathrm{~V}$ the calculated voltammograms are substracted from the experimental one to obtain the $E-I$ curve corresponding to the $\mathrm{NO}_{3}^{-}$ ion discharge, which is finally compared to those already known (Figs. 26 and 27). 


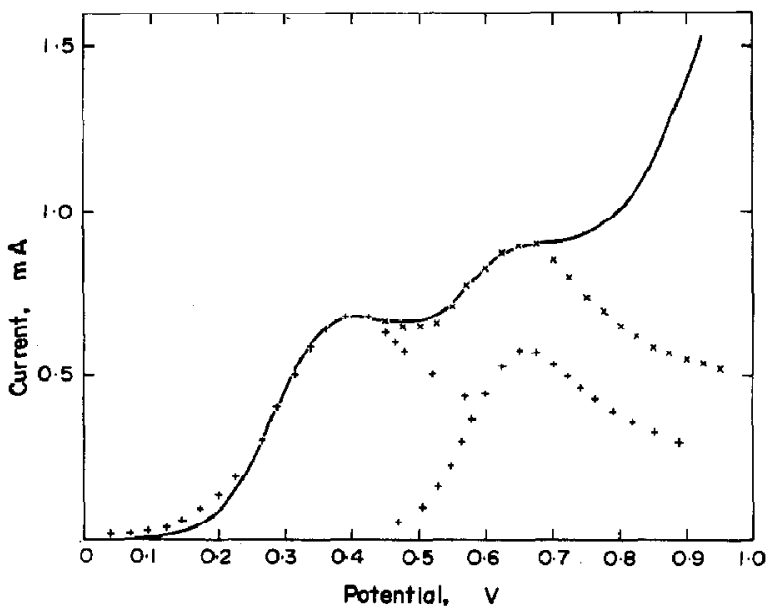

Fig. 26. Experimental and calculatıd voltammograms at $10 \mathrm{mV} / \mathrm{s}$ for graphite/molten nitrate at $244^{\circ} \mathrm{C}$. (+) independent reactions; $(x)$ theoretical voltammogram; full line corresponds to the experimental one. $\mathrm{NO}_{3}^{-}$ion discharge was not considered in the calculations.

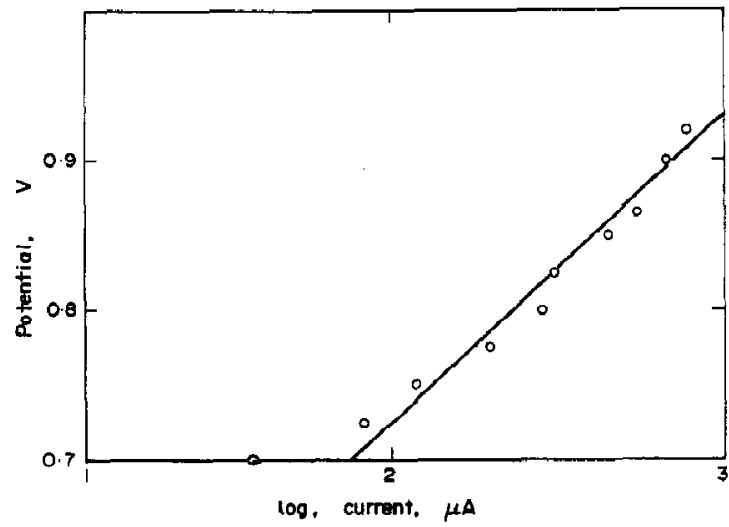

Fig. 27. Tafel line for $\mathrm{NO}_{3}^{-}$ion discharge on graphite obtained by subtracting the calculated voltammograms from the ex perimental ones as indicated in Fig. 21. The slope of the line is $2 \cdot 3(2 R T / F)$.

To construct the anodic voltammogram related to the $\mathrm{O}_{2}^{-}+\mathrm{NO}$ electrochemical reaction, an equation similar to (35) was employed assuming that the initial electron transfer is rate determining and the subsequent thermal reactions are fast. For the voltammogram corresponding to the $\mathrm{NO}_{2}^{-}$ion oxidation, equation (35) was also used on the assumption that at the potential where the reaction occurs, the influence of the $\mathrm{NO}_{3}^{-}$ion electro-oxidation is negligible. A correction due only to the reaction occurring at the cathodic side of the $\mathrm{NO}_{2}^{-}$ion current peak was considered. In spite of the various crude approximations made the $E-I$ curve obtained for the $\mathrm{NO}_{3}^{-}$ion oxidation is in reasonably agreement with those reported previously[1,2].

The above discussion attempts to explain also the different electrochemical behaviour of graphite and platinum in strongly oxidising melts, as well as the observation made by Laitinen and Bathia that the reversible oxide electrode obtained on platinum using oxygen saturated chloride melts, was no longer observed when carbon (graphite) was employed[89].

Acknowledgement - This work is part of the research program of INIFTA, sponsored by the Universidad de La Plata, the Consejo Nacional de Investigaciones Cientificas y Técnicas of Argentina and the Comision de Investigaciones Científicas de la Provincia de Buenos Aires. M.G.S. acknowledges the scholarship granted by C.I.C.

\section{REFERENCES}

1. W. E. Triaca and A. J. Arvia, Electrochim. Acta 11, 955 (1966).

2. A. J. Arvía and W. E. Triaca, An. Asoc. quím. argent. 56, 955 (1968).

3. W. E. Triaca, H. A. Videla and A. J. Arvia, Electrochim. Acta 15, 9 (1970).

4. G. Paus, A. J. Calandra and A. J. Arvía, An. Soc. cient. argent. 192, 35 (1971).

5. M. E. Martins, A. J. Calandra and A. J. Arvia, Electrochim. Acta 15, 111 (1970).

6. P. G. Zambonin, J. electroanal. Chem. 24, 365 (1970).

7. L. E. Topol, R. A. Osteryoung and J. H. Christie, J. phys. Chem. 70, 2857 (1966).

8. P. G. Zambonin and J. Jordan, J. Am. chem. Soc. 91, 2225 (1969).

9. H. Lux. Z. Elkktrochem. 45, 303 (1939).

10. H. Flood, T. Forland and K. Grjotheim, Z, anorg. allg. Chem. 276, 289 (1954).

11. H. Flood, Discuss. Faraday Soc. 1, 302 (1947).

12. F. R. Duke and M. L. Iverson, Analyt. Chem. 31, 1233 (1959).

13. F. R. Duke. J, chem. Educ. 39, 57 (1962).

14. R. N. Kust and F. R. Duke, J. Am. chem. Soc. 85, 3338 (1963).

15. W. E. Triaca and A. J. Arvia, Electrochim. Acta 10, 409 (1965).

16. J. A. A. Ketelaar and A. Dammers-de-Klerk, Rec. Trav. chim. Pays-Bas 83, 322 (1964).

17. M. Francini and S. Martini, EURATOM Document 2496e, Ispra (1965).

18. A. M. Shams El Din, Electrochim. Acta 7, 285 (1962).

19. J. Jordan, J. electroanal. Chem. 29, 127 (1971).

20. P. G. Zambonin, J. electroanal. Chem. 24, App. 25 (1970).

21. J. Jordan, W. B. McCarthy and P. G. Zambonin, Characterization and Analysis in Molten Salts (Edited by G. Mamantov). Dekker, New York (1969).

22. P. G. Zambonin and J. Jordan. J. Am. chem. Soc. 89, 6365 (1967).

23. H. S. Swofford and P. G. McCormick, Analyt. Chem. 37, 970 (1965).

24. A. M. Shams E1 Din and A. A. El Hosary, Electrochim. Acta 12, 1665 (1967).

25. A. A. El Hosary and A. M. Shams El Din, J. electroanal. Chem. 35, 35 (1972).

26. S. Karpacheff and W. Patzug, Z. physik. Chem. 173, 383 (1935).

27. W. E. Triaca and A. J. Arvía, Electrochim. Acta 9, 1055 (1964).

28. N. Gupta and B. R. Sundheim, $J$, electrochem. Soc. 112, 876 (1965). 
29. K. W. Fung and G. Mamantov, Electroanalytical Chemistry in Molten Salts. Adv. Molten Salt Chem. (in press).

30. P. G. McCormick and H. S. Swofford, Analyt. Chem. 41, 146 (1969).

31. G. G. Bombi, R. Freddi and M. Fiorani, Annls. Chim. 56, 759 (1966).

32. Yu. S. Lyalikov, Zh. analit. Khim. 8, 38 (1953); C.A. 47, $5273(1953)$.

33. A. J. Calandra and A. J. Arvía, Electrochim. Acta 11, 1173 (1966).

34. A. J. Arvía and A. J. Calandra, Electrochim. Acta 12, 1441 (1967).

35. R. S. Nicholson and 1. Shain, Analyt. Chem. 36, 706 (1964).

36. G. J. Hills and K. E. Johnson, Adv. Polarography 3, 974.

37. A. J. Calandra, A. J. Arvía and M. E. Martins, Electrochim. Acta 11, 963 (1966).

38. A. J. Calandra, A. J. Arvía and M. E. Martins, Electrochim. Acta 12, 347 (1967).

39. H. E. Bartlett and K. E. Johnston, J. electrochem. Soc. 114, 64 (1967).

40. H. S. Swofford and H. A. Laitinen, J. electrochem. Soc. 110, 814 (1963).

41. K. Ohashi, K. Sasaki and S. Nagaura, Bull. chem. Soc. Japan 39, 2066 (1966).

42. K. Sasaki and K. Ohashi, Electrachim. Acta 12, 366 (1967).

43. A. J. Arvia, A. J. Calandra and N. Tacconi, in preparation.

44. A. R. Ubbelohde and F. A. Lewis, Graphite and its Crystal Compounds. Oxford Univ. Press (1960).

45. A. A. El Hosary and A. M. Shams El Din, Electrochim. Acta 16, 143 (1971).

46. J. S. Mattson, L. Lee, H. B. Mark and W. J. Weber, J. Colloid Interface Sci. 33, 284 (1969).

47. R. Phillips, F. J. Vastola and P. L. Walker, Carbon 8, 197 (1970).

48. U. Wiesmann, Carbon 8, 105 (1970).

49. F. M. Lang, M. de Noblet and M. Brie, Carbon 7, 433 (1969).

50. R. C. Bansal, F. J. Vastola and P. L. Walker, J. Colloid. Interface Sci. 32, 187 (1970).

51. B. R. Puri, S. C. Anand and N. K. Sandle, Indian J. Chem. 4, 310 (1966).

52. H. Marsh, T. E. O'Hair and L. Wynne-Jones, Carbon 7, 555 (1969).

53. R. Sappok and H, P. Boehm, Carbon 6, 283 (1968).

54. D. J. Allerdice, Carbon 3, 215 (1965).

55. R. Sappok and H. P. Boehm, Carbon 6, 573 (1968),

56. H. P. Boehm, Adv. Catalysis 16, 179 (1964).

57. J. B. Donnet, Carbon 6, 161 (1968).

58. P. J. Hart, F. J. Vastola and P. L. Walker, Carbon 5, 363 (1967).

59. V. L. Snoeyink and W. J. Weber, Environ. Sci. Technol. $1,228(1967)$
60. F. P. Bowden and E. K. Rideal, Proc. R. Soc. A120, 80 (1928).

61. H. D. Allendorf and D. E. Rosner, Carbon 7, 515 (1969).

62. J. Nagle and R. F. Strickland-Constable, Proc. 5th Conf. on Carbon 1, 154 (1962).

63. P. Rebandieres and H. Guèrin, C.r. hehd. Seanc. Acad. Sci, Paris 262, 1609 (1966).

64. M. Coltharp and N. Hackerman, J. phys. Chem. 72, 1171 (1968).

65. D. J. Allerdice, Carbon 4, 255 (1966).

66. S. J. Gregg and R. F. S. Tyson, Carbon 3, 39 (1965).

67. K. E. Carr, Carbon 8, 245 (1970).

68. R. Wignand, C.r. hebd. Séanc. Acad. Sci., Paris 260, 6864 (1965).

69. E. L. Evans, R. J. M. Griffiths and J. M. Thomas, Science 171, 174 (1971).

70. S. S. Barton, D. Gillespie and B. H. Harrison, Nature 234, 134 (1971).

71. H. Marsh and T. E. O'Hair, Carbon 7, 702 (1969).

72. G. R. Henning, Carbon 3, 107 (1965).

73. E. Papirer, J, B. Donnet and A. Schutz, Carbon 5, 113 (1967).

74. Yu. A. Zarif'yants, Russ. J. phys. Chem. 38, 1439 (1964).

75. H. A. Resing, J. K. Thompson and J. J. Krebs, J. phys. Chem. 68, 1621 (1964).

76. I. M. Kolthoff and N. Tanakil, Analyt. Chrm. 26, 632 (1954).

77. F. C. Anson and J. J. Lingane, J. Am. chem. Soc. 79, 4901 (1957).

78. J. K. Lee, R. N. Adams and C. E. Bricker, Anal. chim. Acta 17, 321 (1957).

79. H. A. Laitinen and C. G. Enke, J. electrochem. Soc. 107, 773 (1957).

80. J. S. Mayell and S. H. Langer, J. electrochem. Soc. 111 , 438 (1964).

81. G. Mamantov, D. B. Freeman, F. J. Miller and H. E. Zittel. J. electroanal. Chem. 9, 305 (1965).

82. K. Wiesener, Z. physik. Chem. 242, 261 (1969).

83. D. N. Strazhesko and E. S. Matskevich, Elektrokhimi ya 1, $250(1965)$.

84. A. N. Frumkin, V. S. Bagotskii, Z. A. Iofa and B. N. Kabanov, The Kinetics of Electrode Reactions. Izd. MGU. (1952).

85. N. G. Bardina and L. I. Krishtalik, Soviet Electrochem. 2, 307 (1966).

86. S. I. Rempel, Anodic Processes in the Electrolysis of Aluminium, Scientific edn Sverdlosk, U.S.S.R. (1961).

87. D. Dumas and J. Brenet, C.r. hehd. Séanc. Acad. Sci., Paris 265C, 1395 (1967).

88. R. Littlewood and E. J. Argent, Electrochim. Acta 4, 114 (1961).

89. H. A. Laitinen and B. B. Bathia, J. electrochem. Soc. $107,705(1960)$. 